\title{
The large-scale evolution of neodymium isotopic composition in the global modern and Holocene ocean revealed from seawater and archive data
}

\author{
Tachikawa Kazuyo ${ }^{1,{ }^{*}}$, Arsouze Thomas ${ }^{2,3}$, Bayon Germain ${ }^{4}$, Bory Aloys ${ }^{5}$, Colin Camille ${ }^{6}$, \\ Dutay Jean-Claude ${ }^{7}$, Frank Norbert ${ }^{8}$, Giraud Xavier ${ }^{1}$, Gourlan Alexandra T. ${ }^{9}$, Jeandel Catherine ${ }^{10}$, \\ Lacan François ${ }^{10}$, Meynadier Laure ${ }^{11}$, Montagna Paolo ${ }^{12}$, Piotrowski Alexander M. ${ }^{13}$, \\ Plancherel Yves ${ }^{14}$, Pucéat Emmanuelle ${ }^{15}$, Roy-Barman Matthieu ${ }^{7}$, Waelbroeck Claire' ${ }^{7}$
}

\footnotetext{
${ }^{1}$ Aix Marseille Univ, CNRS, IRD, Coll France, CEREGE, Aix-en-Provence, France

${ }^{2}$ Laboratoire de Météorologie Dynamique, École Polytechnique, Palaiseau, France

${ }^{3}$ ENSTA ParisTech, Université Paris-Saclay, 828 bd des Maréchaux, 91762 Palaiseau cedex, France

${ }^{4}$ IFREMER, Unité de Recherche Géosciences Marines, F-29280 Plouzané, France

${ }^{5}$ Université de Lille, CNRS, Université du Littoral Côte d'Opale, UMR8187, LOG, Laboratoire

d'Océanologie et de Geéosciences, F-59000 Lille, France

${ }^{6}$ Laboratoire Geosciences Paris-Sud (GEOPS), Université de Paris Sud, Université Paris-Saclay,

91405 Orsay, France

${ }^{7}$ Laboratoire des Sciences du Climat et de I'Environnement LSCE/IPSL, CEA-CNRS-UVSQ, Université

Paris-Saclay, 91191 Gif-sur-Yvette, France

${ }^{8}$ Institute of Environmental Physics, University of Heidelberg, 69120 Heidelberg, Germany

${ }^{9}$ Université Grenoble Alpes, ISTerre, CS 40700, 38058 Grenoble Cedex 9, France

${ }^{10}$ LEGOS (Université de Toulouse/CNRS/CNES/IRD/UPS), Observatoire Midi-Pyrénées, Toulouse,

France

${ }^{11}$ Equipe de Géochimie-Cosmochimie, Institut de Physique du Globe de Paris - Sorbonne Paris Cité,

Université Paris Diderot, UMR CNRS 7154, 1 rue Jussieu, 75005 Paris, France

${ }^{12}$ ISMAR-CNR, via Gobetti 101, 40129 Bologna, Italy

${ }^{13}$ Department of Earth Sciences, University of Cambridge, Cambridge, UK

${ }^{14}$ Department of Earth Sciences, University of Oxford, Oxford OX1 3AN, UK

${ }^{15}$ UMR CNRS 6282 Biogéosciences, 6 Bd. Gabriel, 21000 Dijon, France

*Corresponding author : Kazuyo Tachikawa, email address : kazuyo@cerege.fr
}

\begin{abstract}
:
Neodymium isotopic compositions $\left({ }^{143} \mathrm{Nd} /{ }^{144} \mathrm{Nd}\right.$ or $\left.\varepsilon \mathrm{Nd}\right)$ have been used as a tracer of water masses and lithogenic inputs to the ocean. To further evaluate the faithfulness of this tracer, we have updated a global seawater $\varepsilon N d$ database and combined it with hydrography parameters (temperature, salinity, nutrients and oxygen concentrations), carbon isotopic ratio and radiocarbon of dissolved inorganic carbon. Archive $\varepsilon N d$ data are also compiled for leachates, foraminiferal tests, deep-sea corals and fish teeth/debris from the Holocene period $(<10,000$ years).
\end{abstract}

At water depths $\geq 1500 \mathrm{~m}$, property-property plots show clear correlations between seawater $\varepsilon N d$ and 
the other variables, suggesting that large-scale water mass mixing is a primary control of deepwater $\varepsilon N d$ distribution. At $\geq 200 \mathrm{~m}$, basin-scale seawater T-S- $\varepsilon N d$ diagrams demonstrate the isotopic evolution of different water masses. Seawater and archive $\varepsilon N d$ values are compared using property-property plots and T-S- $\varepsilon N d$ diagrams. Archive values generally agree with corresponding seawater values although they tend to be at the upper limit in the Pacific. Both positive and negative offsets exist in the northern North Atlantic. Applying multiple regression analysis to deep $(\geq 1500 \mathrm{~m})$ seawater data, we established empirical equations that predict the main, large-scale, deepwater $\varepsilon N d$ trends from hydrography parameters. Large offsets from the predicted values are interpreted as a sign of significant local/regional influence. Dominant continental influence on seawater and archive $\varepsilon N d$ is observed mainly within 1000 $\mathrm{km}$ from the continents. Generally, seawater and archive $\varepsilon N d$ values form gradual latitudinal trend in the Atlantic and Pacific at depths $\geq 600 \mathrm{~m}$, consistent with the idea that $\mathrm{Nd}$ isotopes help distinguish between northern/southern sourced water contributions at intermediate and deep water depths.

Keywords : Nd isotopes, Water mass tracer, Data compilation, Predicted seawater $\varepsilon N d$, Seawaterarchive comparison 


\section{Introduction}

Neodymium is one of the Rare Earth Elements (REE) and consists of seven isotopes. One of the isotopes, ${ }^{143} \mathrm{Nd}$, is an $\alpha$-decay product of ${ }^{147} \mathrm{Sm}$ that also belongs to REE with a half-life of $1.06 \times 10^{11}$ years. Since $\mathrm{Sm} / \mathrm{Nd}$ ratio in rocks and minerals varies during crystallization from magma, ${ }^{143} \mathrm{Nd} /{ }^{144} \mathrm{Nd}$ of continental materials change as a function of age and lithology. Seawater ${ }^{143} \mathrm{Nd} /{ }^{144} \mathrm{Nd}$ ( or $\varepsilon_{\mathrm{Nd}}=\left[\left({ }^{143} \mathrm{Nd} /{ }^{144} \mathrm{Nd}\right)_{\text {sample }} /\left({ }^{143} \mathrm{Nd} /{ }^{144} \mathrm{Nd}\right)_{\mathrm{CHUR}}-1\right] \times 10^{4}$, CHUR is a Chondritic Uniform Reservoir with ${ }^{143} \mathrm{Nd} /{ }^{144} \mathrm{Nd}$ of 0.512638 (Jacobsen and Wasserburg, 1980) or of 0.512630 (Bouvier et al., 2008)) reflects the isotopic signature of continents surrounding the oceanic basins. In the modern ocean, the lowest seawater $\varepsilon_{\mathrm{Nd}}$ value of -26.6 is observed in the Baffin Bay (Stordal and Wasserburg, 1986) encompassed by old craton whereas the most radiogenic value of +2.7 is found in the Eastern Equatorial Pacific where young volcanogenic material is abundant (Grasse et al., 2012). The estimated residence time of $\mathrm{Nd}$ in the ocean of 360 to 700 years (Tachikawa et al., 2003; Siddall et al., 2008; Rempfer et al., 2011) is shorter than mean mixing time of deep ocean of about 1500 years (Broecker and Peng, 1982). This explains the heterogeneous distribution of deepwater $\varepsilon_{\mathrm{Nd}}$ 
values, and $\mathrm{Nd}$ isotopes have been used as a tracer of ocean circulation in the present and past ocean (Albarède and Goldstein, 1992; von Blanckenburg, 1999; Frank, 2002; Goldstein and Hemming, 2003; Thomas, 2004; Robinson et al., 2010; Lacan et al., 2012).

This basic idea is however oversimplified, and the knowledge on specific processes/mechanisms controlling oceanic $\varepsilon_{\mathrm{Nd}}$ distribution has been progressing. The net external $\mathrm{Nd}$ sources to the ocean have been shown to be partially dissolved dust and river particles as well as river water (Tachikawa et al., 1999a; von Blanckenburg, 1999; Frank, 2002; Goldstein and Hemming, 2003 ). In addition, the contribution of groundwater is suggested (Johannesson and Burdige, 2007) whereas hydrothermalism functions as sink of oceanic Nd (Zheng et al., 2016), although it was hypothesized that it could modify the local seawater isotopic signature through "Ridge exchange" processes (Jeandel et al., 2013).

It is however impossible to reproduce the observed seawater $\varepsilon_{\mathrm{Nd}}$ contrast between the deep Atlantic and the deep Pacific only accounting for these net continental sources and physical mixing of water masses (Tachikawa et al., 2003; Jones et al., 2008). Reversible scavenging, an interaction of $\mathrm{Nd}$ between dissolved and particulate phases, is a fundamental process for the vertical transport of the Nd isotopic signature (Bertram and Elderfield, 1993; Jeandel et al., 1995; Tachikawa et al., 1999b). In particular, the reaction along continental margins called "Boundary Exchange (BE)" is a key process and supported by both field observation (Lacan and Jeandel, 2005; Rickli et al., 2009; Rickli et al., 2010; Carter et al., 2012; Stichel et al., 2012; Wilson et al., 2012; Grenier et al., 2013) and modeling experiments (Arsouze et al., 2007; Siddall et al., 2008; Arsouze et al., 2009; Rempfer et al., 2011). Nonetheless, the exact mechanisms of BE remain to be elucidated (Jeandel, 2016), and its geographical extension should be better constrained since in such areas seawater $\varepsilon_{\mathrm{Nd}}$ values are not a straightforward water mass tracer. Recently, the first measurements of pore water $\mathrm{Nd}$ isotopic composition suggested the contribution of radiogenic pore water $\mathrm{Nd}$ to shallow and 
intermediate waters on the Northwestern Pacific margin (Abbott et al., 2015; Abbott et al., 2016). Also, a possible influence of unradiogenic Nd from poorly chemically weathered detrital material on bottom water was proposed for the Northern northwestern Atlantic (Howe et al., 2016b). These findings may explain different aspects of BE.

Over the last several decades, the interest in $\mathrm{Nd}$ isotopes has been increasing with a growing body of high quality and highly resolved data, thanks to the GEOTRACES program, and the identification of archives that can record and preserve seawater $\mathrm{Nd}$ isotopic signatures. Indeed, $\mathrm{Nd}$ isotopes are a rare tracer that allows reconstructing past oceanic circulation on timescale ranging from Jurassic to late Pleistocene (Puceat et al., 2005; Gourlan et al., 2008; Dera et al., 2009; van de Flierdt and Frank, 2010; Charbonnier et al., 2012; Martin et al., 2012; Moiroud et al., 2013; Thomas et al., 2014; Le Houedec et al., 2016 and Frank, 2002; Goldstein and Hemming, 2003 for review) using various archives.

Biogenic apatite (fish teeth/debris) has been considered one of the most reliable recorders of seawater Nd isotopic compositions (Martin and Haley, 2000; Martin and Scher, 2004; Martin et al., 2010; Horikawa et al., 2011) although the occurrence of this archive is not constant and barren samples are not uncommon. The use of deep-sea corals is relatively recent. The advantages are the possibility of precise U-Th dating and high-resolution reconstruction (Robinson and van de Flierdt, 2009; Colin et al., 2010; Copard et al., 2010; van de Flierdt et al., 2010; Copard et al., 2011; Wilson et al., 2014). However, certain time intervals are bare of this archive under hostile environmental conditions for the organism (Frank et al., 2011). Bulk carbonate fraction (Gourlan et al., 2008; Le Houedec et al., 2016) is also used for carbonate-rich sediments.

Sedimentary dispersive Fe-Mn oxyhydroxides extracted with various leaching techniques have been widely used because of their ubiquitous presence in marine sediments and temporal resolution to possibly resolve glacial-interglacial and millennial changes 
(Rutberg et al., 2000; Bayon et al., 2002; Piotrowski et al., 2004; Piotrowski et al., 2005; Gutjahr et al., 2007; Gutjahr et al., 2008; Haley et al., 2008a; Haley et al., 2008b; Pahnke et al., 2008; Piotrowski et al., 2009; Crocket et al., 2011; Gutjahr and Lippold, 2011). A potential difficulty of this archive is the possible contamination from labile terrigenous fraction such as preformed continental Fe-Mn oxyhydroxides and volcanogenic material (Bayon et al., 2004; Roberts et al., 2010; Elmore and Wright, 2011; Piotrowski et al., 2012; Ehlert et al., 2013; Kraft et al., 2013; Wilson et al., 2013; Wu et al., 2015b; Abbott et al., 2016; Blaser et al., 2016). To minimize the risk, sedimentary oxyhydroxides attached on foraminiferal tests have been used to reconstruct bottom water $\mathrm{Nd}$ isotopic compositions since fine detrital fraction can be mechanically removed from foraminiferal tests (Roberts et al., 2010; Elmore and Wright, 2011; Charbonnier et al., 2012; Pena and Goldstein, 2014; Tachikawa et al., 2014; Wu et al., 2015b). However, it has been recently proposed that sedimentary oxyhydroxides record pore water rather than bottom water $\mathrm{Nd}$ isotopic composition, so that the observed discrepancies between archives and seawater isotopic signature could be explained at least partly by the different $\varepsilon_{\mathrm{Nd}}$ values between bottom and pore waters (Du et al., 2016).

The main challenges to further improve the application of $\mathrm{Nd}$ isotopes to modern and paleo-oceanography studies are (1) to estimate the spatial extension of areas where seawater $\varepsilon_{\mathrm{Nd}}$ values are highly affected by local/regional detrital inputs and (2) to evaluate the faithfulness of archive $\varepsilon_{\mathrm{Nd}}$ values as an indicator of bottom water masses. For these objectives, we have updated a database of the available seawater $\mathrm{Nd}$ isotopic compositions, and compiled $\varepsilon_{\mathrm{Nd}}$ values from foraminiferal coatings, deep-sea corals, fish teeth/debris and various leachates from the Holocene period $(<10,000$ years) in the framework of the French INSU/LEFE project NEOSYMPA (Workshop NEOdymium isotopes in marine environments: SYnergy between Modern, Modelling and PAleo communities). The seawater and archive 
database contains hydrography parameters (temperature, salinity, silicate, phosphate and oxygen concentrations) from original publications and World Ocean Atlas 2009 (WOA09) (Antonov et al., 2010; Garcia et al., 2010a; Garcia et al., 2010b; Locarnini et al., 2010), carbon isotopic ratio $\left({ }^{13} \mathrm{C} /{ }^{12} \mathrm{C}\right.$ or $\left.\delta^{13} \mathrm{C}\right)$ of dissolved inorganic carbon (DIC) from the global $\delta^{13} \mathrm{C}$ compilation (Schmittner et al., 2013) and natural (background or pre-bomb) $\Delta^{14} \mathrm{C}$ values from GLODAP database (Key et al., 2004). The database contains also the distance of each data station from the nearest continental margin. Using this new database, we provide novel insight into oceanic $\mathrm{Nd}$ cycle.

\section{Construction of NEOSYMPA global database of seawater and archives Nd isotopes}

The seawater Nd database of Lacan et al. (2012) has been updated by integrating all seawater $\varepsilon_{\mathrm{Nd}}$ data published up to September 2016 to our knowledge (Figure 1) (Bayon et al., 2011; Grenier et al., 2011; Carter et al., 2012; Grasse et al., 2012; Singh et al., 2012; Stichel et al., 2012; Amakawa et al., 2013; Chen et al., 2013b; Ehlert et al., 2013; Jeandel et al., 2013; Freslon et al., 2014; Garcia-Solsona et al., 2014; Goswami et al., 2014; Haley et al., 2014; Huang et al., 2014; Werner et al., 2014; Abbott et al., 2015; Basak et al., 2015; Stichel et al., 2015; Wu et al., 2015a; Du et al., 2016; Dubois-Dauphin et al., 2016a; Fröllje et al., 2016; Lambelet et al., 2016; Dubois-Dauphin et al., submitted). Following the approach of the previous compilation (Lacan et al., 2012), we focus on seawater $\mathrm{Nd}$ isotopic compositions. Dissolved (filtered and unfiltered) Nd concentrations are included in the database if they are reported with corresponding isotopic results. Considering the general agreement of seawater $\mathrm{Nd}$ isotopic compositions obtained by various analytical techniques during different time spans (Lacan et al., 2012; van de Flierdt et al., 2012), no distinction was made between analytical methods. Some Nd data from low salinity waters (salinity 5-30 psu) are included in the database although the major focus of this study is on waters with salinity $\geq 30 \mathrm{psu}$. The 
vertical distribution of seawater stations is heterogeneous with more abundant data for surface/subsurface (Figure 1).

In contrast to the previous compilations (Lacan et al., 2012; van de Flierdt et al., 2016) and an on-going construction of GEOTRACES database, NEOSYPA database includes $\delta^{13} \mathrm{C}$ and $\Delta^{14} \mathrm{C}$ values of DIC extracted from global databases (Key et al., 2004; Schmittner et al., 2013) as well as lateral distances from the data stations to the nearest continental margins at the ocean surface, in addition to hydrography parameters (temperature, salinity, dissolved silica, phosphate and oxygen concentrations). If the hydrographical parameters are not available in original publications, they were extracted from the closest station in WOA09 database (Antonov et al., 2010; Garcia et al., 2010a; Garcia et al., 2010b; Locarnini et al., 2010). The hydrography parameters from WOA09 and original publications are in good agreement except for temperature and salinity at some coastal stations such as the Amazon river mouth, Bay of Bengal, Gulf of Alaska, Greenland coast and Japan Sea, as well as dissolved silicate and phosphate at two sites in the Southeast Pacific at $650 \mathrm{~m}$ and $1500 \mathrm{~m}$ (Figure S1).

NEOSYMPA database (Table S1) contains $\varepsilon_{\mathrm{Nd}}$ values obtained on sedimentary archives and deep-sea corals (referred as to "archival $\varepsilon_{\mathrm{Nd}}$ values" below) from the following publications (Palmer and Elderfield, 1985; Vance and Burton, 1999; Burton and Vance, 2000; Rutberg et al., 2000; Freydier et al., 2001; Bayon et al., 2002; Bayon et al., 2004; Piotrowski et al., 2004; Scrivner et al., 2004; Tachikawa et al., 2004; Vance et al., 2004; Gutjahr et al., 2007 ; Stoll et al., 2007; Gutjahr et al., 2008; Haley et al., 2008a; Haley et al., 2008b; Klevenz et al., 2008; Pahnke et al., 2008; Piotrowski et al., 2008; Yu et al., 2008; Piotrowski et al., 2009; Robinson and van de Flierdt, 2009; Basak et al., 2010; Colin et al., 2010; Copard et al., 2010; Gourlan et al., 2010; Murphy and Thomas, 2010; Roberts et al., 2010; Stumpf et al., 2010; van de Flierdt et al., 2010; Bayon et al., 2011; Copard et al., 2011; Elmore et al., 2011; 
Horikawa et al., 2011; Asahara et al., 2012; Carter et al., 2012; Chen et al., 2012; López Correa et al., 2012; Piotrowski et al., 2012; Wilson et al., 2012; Xie et al., 2012; Haley and Polyak, 2013; Jang et al., 2013; Kraft et al., 2013; Maccali et al., 2013; Montero-Serrano et al., 2013; Noble et al., 2013; Pena et al., 2013; Skinner et al., 2013; Achyuthan et al., 2014; Huang et al., 2014; Molina-Kescher et al., 2014; Werner et al., 2014; Jiménez-Amat and Zahn, 2015; Jonkers et al., 2015 ; Roberts and Piotrowski, 2015; Abbott et al., 2016; Blaser et al., 2016; Du et al., 2016; Dubois-Dauphin et al., 2016b ; Howe et al., 2016a; Hu et al., 2016 ; Lang et al., 2016; Lippold et al., 2016; Meinhardt et al., 2016 ; Wei et al., 2016) (Figure 1). Each archival value is accompanied by all the above-mentioned auxiliary data from various sources (Key et al., 2004; Antonov et al., 2010; Garcia et al., 2010a; Garcia et al., 2010b; Locarnini et al., 2010; Schmittner et al., 2013) and distances from the continents.

We classified the archives into seven categories: sedimentary foraminiferal coatings (referred as to "foraminifera" below), dispersive Fe-Mn oxyhydroxides obtained with hydroxylamine hydrochloride $(\mathrm{HH})$ leaching after decarbonation, $\mathrm{HH}$ leachate obtained from bulk sediments, acetic acid (AA) leachate from bulk sediments, other leachates (for example, $\mathrm{HCl}$ leaching), deep-sea corals, and fish teeth/debris. Regarding to the $\mathrm{HH}$ leachates, the presence and absence of decarbonation is distinguished because this step induces significant differences in $\mathrm{Nd}$ isotopic composition, and recent studies recommend omitting decarbonation (Wilson et al., 2012; Kraft et al., 2013; Wu et al., 2015b; Blaser et al., 2016). To improve the spatial coverage of archive data, we gathered all data with age $<10,000$ years, even if we are aware that seawater $\varepsilon_{\mathrm{Nd}}$ values could vary during Holocene as shown by deep-sea corals from the North Atlantic (Colin et al., 2010; Montero-Serrano et al., 2011; Copard et al., 2012). When the evidence of age $<10,000$ years is provided, the data are included in the database in spite of the absence of absolute age. The archive data are better distributed vertically compared to seawaters without a predominant surface maximum (Figure 1). 
Both seawater and archive data are classified into seven oceanic basins (Atlantic, Southern Ocean, Indian, Pacific, Arctic and Mediterranean Sea). Our focus of this paper is on the open oceans that create the global general trends. Because of this reason, we treat essentially the data from the Atlantic, the Pacific, the Indian and the Southern Oceans.

\section{Results}

\subsection{General trends of seawater Nd variability}

Depth profiles of seawater $\mathrm{Nd}$ concentration, seawater $\varepsilon_{\mathrm{Nd}}$ and archive $\varepsilon_{\mathrm{Nd}}$ values are shown for the Atlantic, Southern Ocean, Indian and Pacific with latitudinal trend by color code (Figure 2). Marked surface water Nd enrichment up to $150 \mathrm{pmol} / \mathrm{kg}$ is observed in the North Atlantic, North Indian and North Pacific (Figure 2). In the North Pacific, seawater Nd concentration is systematically higher than the values in the South Pacific at corresponding latitudes and water depths (Figure 2). Seawater $\varepsilon_{\mathrm{Nd}}$ depth-profiles present a larger variability at shallower water depths in the Atlantic, the Indian and the Pacific (Figure 2). Except very radiogenic values $\left(\varepsilon_{\mathrm{Nd}}>-5\right)$ at water depths shallower than $500 \mathrm{~m}$ (referred as to " $<500 \mathrm{~m}$ " below) in the North Atlantic, the Atlantic waters indicate the latitudinal $\varepsilon_{\mathrm{Nd}}$ trend with lower values in the northern North Atlantic $\left(\varepsilon_{\mathrm{Nd}}\right.$ centered at around -13 at $50^{\circ} \mathrm{N}$ to $\left.75^{\circ} \mathrm{N}\right)$, middle values at mi-latitudes $\left(\varepsilon_{\mathrm{Nd}}\right.$ of around -12 at 0 to $\left.30^{\circ} \mathrm{N}\right)$, and higher values of around -9 at southern hemisphere (Figure 2). In contrast, the Pacific $\varepsilon_{\mathrm{Nd}}$ values are lower in the southern hemisphere with a mean $\varepsilon_{\mathrm{Nd}}$ value of around -8 at $\geq 500 \mathrm{~m}$ at $60^{\circ} \mathrm{S}$ to $20^{\circ} \mathrm{S}$ than in equatorial and northern hemisphere with $\varepsilon_{\mathrm{Nd}}$ of about -4 at $\geq 500 \mathrm{~m}$ at 0 to $75^{\circ} \mathrm{N}$ (Figure 2).

These observed features are consistent with the conventional view that the general increase of deepwater $\varepsilon_{\mathrm{Nd}}$ along the global thermohaline circulation pathway is caused by a mixing between young North Atlantic waters with low $\varepsilon_{\mathrm{Nd}}$ values and old Pacific waters with high $\varepsilon_{\mathrm{Nd}}$ values. Deepwater $\varepsilon_{\mathrm{Nd}}$ values $(\geq 1500 \mathrm{~m}$ ) correlate well with dissolved silica and phosphate 
concentrations (Figure 3). The South Atlantic, the Southern Ocean, the South Indian and the South Pacific Ocean waters present intermediate values (Figure 3). However, a conventional binary mixing trend is not evident in seawater $\varepsilon_{\mathrm{Nd}}$ versus $1 /[\mathrm{Nd}]$ plot (here $[\mathrm{Nd}]$ is dissolved Nd concentration of seawater) and the highest $\varepsilon_{\mathrm{Nd}}$ values are observed not only for the deep water in the north Pacific but also in the equatorial Pacific (Figure 3). Taking into account general co-variation between seawater $\varepsilon_{\mathrm{Nd}}$ values and other water mass tracers at water depths deeper than 1500m (Figures 3), deepwater Nd isotopic composition generally reflects water mass mixing but significant local/regional effects exist for some cases. The lack of the conventional binary mixing ( $\varepsilon_{\mathrm{Nd}}$ vs. $\left.1 /[\mathrm{Nd}]\right)$ thus indicates principally non-conservative nature of dissolved Nd concentration.

The property-property plots between $\varepsilon_{\mathrm{Nd}}$ and other water mass indicators (multi-scatter plots) allow us to visually identify the data that are offset from the general mixing envelopes, such as the values from the Caribbean Sea (number 1 in Figure 3), Baffin Bay (number 2 in Figure 3) and Bay of Bengal (number 3 in Figure 3). This is consistent with the statement of original papers suggesting influence of local detrital inputs (Stordal and Wasserburg, 1986; Singh et al., 2012; Osborne et al., 2014). In the following, we use basin-scale multi-scatter plots to examine the regional variance in each oceanic basin in detail.

\subsection{Basin-scale seawater and archive Nd isotopic variability}

\subsubsection{Seawater multi-scatter plots for deep and intermediate waters}

We test the relationships of water masses at $\geq 1500 \mathrm{~m}$ to avoid difficulties related to definition of water mass end-members. For the first approximation, offsets from the general trend are evaluated visually and considered to be significant when more than two propertyproperty plots support the departure. 
In the Atlantic and the Atlantic sector of the Southern Ocean (Figure 4a), the general mixing envelopes are formed between younger, warmer, saltier nutrient-depleted and oxygenrich northern-sourced deep waters with lower $\varepsilon_{\mathrm{Nd}}$, and older, cooler, fresher nutrient-rich and oxygen-depleted southern-sourced waters with higher $\varepsilon_{\mathrm{Nd}}$. Offsets from the general mixing are observed for the stations in the Caribbean Sea (number 1 in Figure 4a), the Labrador Sea (number 2, Figure 4a), along the eastern Greenland coast (number 4, Figure 4a), off Amazon River mouth (number 3, Figure 4a) and a site in Southeastern Atlantic (number 5, Figure 4a), as well as warm and saline Mediterranean Outflow Water (MOW). In contrast, silicate and phosphate data of these sites are on the general mixing trend (Figure 4a), suggesting that the observed seawater $\varepsilon_{\mathrm{Nd}}$ offsets are related to specific behavior of $\mathrm{Nd}$. Clear mixing trend is not expressed in the relationship with $1 /[\mathrm{Nd}]$ and with potential density anomaly (not shown in figure).

The spatial data coverage in the Indian Ocean is not sufficient to determine the mixing envelopes (Figure 4b). We observe regional trends with the most radiogenic seawater $\varepsilon_{\mathrm{Nd}}$ values of -6 to -4 in the easternmost part of the Equatorial Indian Ocean originating from the Sunda Arch Slope (Jeandel et al., 1998) that shows properties close to those of Pacific waters (Figure 3) whereas the waters of $\varepsilon_{\mathrm{Nd}}$ as low as -12 are found in the Bay of Bengal that receive unradiogenic Nd from the Ganga-Brahmaputra river system (Singh et al., 2012) (Figure 4b). The Arabian Sea waters at 1500-1600 m (numbers1 and 2 in Figure 4b) are warmer and saltier than other Indian deep waters.

In the Pacific Ocean and the Pacific sector of the Southern Ocean, deepwater $\varepsilon_{\mathrm{Nd}}$ values correlate well with other water mass indicators, forming mixing envelopes between the younger and colder southern-sourced waters with lower $\varepsilon_{\mathrm{Nd}}$ values of around -8 , and the older and warmer northern and equatorial-sourced waters with higher $\varepsilon_{\mathrm{Nd}}$ values centered at around -4 (Figure 4c). Positive $\varepsilon_{\mathrm{Nd}}$ offsets from the general trend are observed close to Hawaii 
(number 1, Figure 4c), along the eastern Japan coast (number 2, Figure 4c), in the eastern equatorial Pacific (number 3, Figure 4c) and Haxby seamount in the Southern Ocean (number 6, Figure 4c) whereas negative offsets are found east of New Zealand (number 4, Figure 4c) and in the central North Pacific bottom water (number 5, Figure 4c).

Basin-scale multi-scatter plots for the intermediate waters $(600-1500 \mathrm{~m})$ present weaker relationships in all basins (Figure S2abc). The geographical distribution of sites where seawater $\varepsilon_{\mathrm{Nd}}$ values are away from the general tendencies is similar to the deepwater cases with some additional sites including lower $\varepsilon_{\mathrm{Nd}}$ values in the Angola Basin (number 2, Figure S2a) and the Bay of Bengal (white circle in Figure S2b) and higher $\varepsilon_{\mathrm{Nd}}$ values in the Western equatorial Pacific (number 5, Figure S2c).

\subsubsection{Comparison between archive and seawater Nd isotopic compositions}

Basin-scale mixing trends defined by seawater multi-scatter plots allows visual comparison between archive and seawater $\varepsilon_{\mathrm{Nd}}$ values at $\geq 600 \mathrm{~m}$ even if the sampling locations and water depths are not identical for the two types of samples (Figures 5abc and $\mathrm{S} 4 \mathrm{abc})$

For the deep $(\geq 1500 \mathrm{~m})$ Atlantic and the Atlantic sector of the Southern Ocean, the majority of archival $\varepsilon_{\mathrm{Nd}}$ values fall within the domains defined by seawater data except the northern North Atlantic where both positive and negative offsets as large as 10 -units are observed (the large circle on the plots and the red and bleu stations on the map of Figure 5a). The most radiogenic archival $\varepsilon_{\mathrm{Nd}}$ values are found around Iceland and downstream the Iceland-Scotland Overflow Waters at about $40^{\circ} \mathrm{N}$ (Elmore et al., 2011) whereas an about $2 \varepsilon$ unit higher $\varepsilon_{\mathrm{Nd}}$ value is observed at a southernmost site at around $55^{\circ} \mathrm{S}$ on the Mid-Ocean Ridge (number 5 in Figure 5a). Three sites from $50^{\circ} \mathrm{N}$ to $34^{\circ} \mathrm{N}$ along Deep Western Boundary 
Current (numbers 1, 2 and 4 in Figure 5a), and a site in the Angola Basin (number 3 in Figure 5a) present $\varepsilon_{\mathrm{Nd}}$ values lower than expected from the seawater domain (Figure 5a). The archive types showing the offsets are diverse including foraminifera, $\mathrm{HH}$ leachate with decarbonation, fish teeth/debris and AA leachate (Figure 5a).

In the deep Indian Ocean, more negative $\varepsilon_{\mathrm{Nd}}$ values (about 2 to $4 \varepsilon$-units) than the expected seawater signals are found on the northern margin of Madagascar (number 1 in Figure 5b) for foraminifera, $\mathrm{HH}$ leachate with and without decarbonation, being consistent with the original publication (Wilson et al., 2012).

In the deep Pacific and the Pacific sector of the Southern Ocean, the archive $\varepsilon_{\mathrm{Nd}}$ values generally follow the mixing envelopes although they are prone to occupy the domains at upper limits of seawater $\varepsilon_{\mathrm{Nd}}$ values (Figure 5c), as shown by the recent study (Hu et al., 2016). Clear positive $\varepsilon_{\mathrm{Nd}}$ offsets up to $4 \varepsilon$-units are observed for the Gulf of Alaska (numbers 5 to 10 in Figure 5c), the Eastern Equatorial Pacific (numbers 1 to 3 in Figure 5c), near Hawaii (number 4 in Figure 5c), for foraminifera and $\mathrm{HH}$ leachate with and without decarbonation.

The archival $\varepsilon_{\mathrm{Nd}}$ values at intermediate water depths $(600-1500 \mathrm{~m})$ present a larger range of variability than for the deeper depths (Figure S3abc). In the Atlantic, one HH leachate with decarbonation from the eastern Greenland coast where $\varepsilon_{\mathrm{Nd}}$ of continental margin is very high (Jeandel et al., 2007) presents Nd isotopic composition about 10 e-units higher than the water value (number 1 in Figure S3a). In the Indian, only one archive $\varepsilon_{\mathrm{Nd}}$ value is available and it is within the seawater $\varepsilon_{\mathrm{Nd}}$ range (Figure $\mathrm{S} 3 \mathrm{~b}$ ). In the Pacific and the Pacific sector of the Southern Ocean, archive $\varepsilon_{\mathrm{Nd}}$ values are generally within the seawater domain except about 2 e-units more radiogenic data obtained in the Eastern Equatorial Pacific (numbers 1 to 3 in Figure S3c), Amundsen Sea embayment (number 4 in Figure S3c) and Bering Sea (number 5 in Figure S3c). 


\subsection{3. $T-S-\varepsilon_{N d}$ diagrams for seawater and archives}

In order to associate $\varepsilon_{\mathrm{Nd}}$ values with different water masses and evaluate the basinscale isotopic evolution at $\geq 200 \mathrm{~m}$, we use temperature/salinity diagram combined with seawater and archive $\varepsilon_{\mathrm{Nd}}$ values $\left(\mathrm{T}-\mathrm{S}-\varepsilon_{\mathrm{Nd}}\right.$ diagram). In T-S diagram, the $\varepsilon_{\mathrm{Nd}}$ values are shown with color code (Figure 6). The identification of water masses is based on temperature and salinity ranges and the geographical extension (Emery and Meincke, 1986; Amakawa et al., 2009; Bostock et al., 2013). The water masses described below are listed in Tables 1 and S2.

In the Atlantic, the $\mathrm{T}-\mathrm{S}-\varepsilon_{\mathrm{Nd}}$ diagram undoubtedly indicates a latitudinal variation of seawater $\mathrm{Nd}$ isotopic compositions with unradiogenic northern water masses including NADW and various central waters, and more radiogenic southern-sourced waters such as AABW and AAIW (Figure 6a). The mean seawater Nd isotopic composition and the mean $\mathrm{Nd}$ concentration of each water mass (Table 1) can be estimated at a given temperature and salinity range, and the geographical extension of the water mass (Table $\mathrm{S} 2$ ). The $\varepsilon_{\mathrm{Nd}}$ value and the dissolved Nd concentration of NADW are estimated at $-12.3 \pm 0.9(1 \sigma, \mathrm{n}=173)$ and $20.3 \pm 3.2(\mathrm{pmol} / \mathrm{kg})(1 \sigma, \mathrm{n}=135)$, respectively (Table 1). This NADW $\varepsilon_{\mathrm{Nd}}$ value is in an excellent agreement with a recent estimation of $-12.4 \pm 0.4(2 \sigma)$ (Lambelet et al., 2016) that focuses on the North western Atlantic data. AABW and AAIW in the South Atlantic are characterized by the $\varepsilon_{\mathrm{Nd}}$ values of $-8.6 \pm 0.6(1 \sigma, \mathrm{n}=39$, Table 1$)$ and $-8.6 \pm 1.4(1 \sigma, \mathrm{n}=28)$, respectively (Table 1). The archive data are concentrated on the mixing line between AABW and NADW, and $\varepsilon_{\mathrm{Nd}}$ values close to the core of NADW are often higher than corresponding seawater data (Figure 6b). This is consistent with the observation based on the propertyproperty plots (Figure 5a).

In the Indian Ocean (Figure 6c), the most radiogenic seawater $\mathrm{Nd}$ isotopic compositions of -5 to -4 are observed for Indonesian Intermediate Water (IIW) at intermediate water depths that occupies easternmost equatorial basin (Emery and Meincke, 1986). An array 
of unradiogenic $\varepsilon_{\mathrm{Nd}}$ values of about -12 at salinity of around 35 (Figure 6c) is found in the Bay of Bengal. The mean $\varepsilon_{\mathrm{Nd}}$ values for CDW and AAIW in the South Indian are $-7.9 \pm 1.3$ $(1 \sigma, \mathrm{n}=10$, Table 1$)$ and $-7.6 \pm 0.9(1 \sigma, \mathrm{n}=4$, Table 1$)$, respectively. Archive $\varepsilon_{\mathrm{Nd}}$ data are very limited in the Indian Ocean and cover only a few water masses (Figure 6d).

The most striking feature in the Pacific Ocean is very high seawater $\varepsilon_{\mathrm{Nd}}$ values for EqPIW (Bostock et al., 2013) at 500-1500 $\mathrm{m}$ and PEW at 0-500 $\mathrm{m}$ (Emery and Meincke, 1986) (Table 1 and Figure 6e). NPIW is also characterized by an elevated Nd isotopic composition (Table 1 and Figure 6e). The mean $\varepsilon_{\mathrm{Nd}}$ values of EqPIW, PEW and NPIW are 3.0 $\pm 1.4(1 \sigma, n=31),-2.1 \pm 0.9(1 \sigma, n=72)$ and $-3.4 \pm 1.3(1 \sigma, n=12)$, respectively (Table 1$)$. The deeper water and southern-sourced waters have lower mean $\varepsilon_{\mathrm{Nd}}$ values with $-4.3 \pm 1.2$ $(1 \sigma, \mathrm{n}=84),-7.7 \pm 1.1(1 \sigma, \mathrm{n}=21)$ and $-7.8 \pm 1.2(1 \sigma, \mathrm{n}=92)$ for NPDW, AAIW and CDW in the Pacific, respectively (Table 1). EqPIW is a mixture of AAIW and upwelled old NPDW (Bostock et al., 2013). Since the Nd isotopic composition of AAIW and NPDW are lower than the value of EqPIW (Figure 6e, Table 1), additional radiogenic Nd supply is required (Lacan and Jeandel, 2001; Grenier et al., 2013; Grenier et al., 2014). The NPIW formation is mainly density driven by sinking in the Okhotsk Sea (Yasuda et al., 1996), and its high $\varepsilon_{\mathrm{Nd}}$ value is explained by a large contribution of radiogenic $\mathrm{Nd}$ supply from the Kuril Islands (Amakawa et al., 2004). Consequently EqPIW, PEW and NPIW are influenced by detrital inputs. The archive $\mathrm{T}-\mathrm{S}-\varepsilon_{\mathrm{Nd}}$ diagram presents $\varepsilon_{\mathrm{Nd}}$ trends similar to the seawater $\mathrm{T}-\mathrm{S}-\varepsilon_{\mathrm{Nd}}$ diagram with radiogenic EqPIW and PEW although the mean $\mathrm{Nd}$ isotopic compositions are about $1 \varepsilon$-unit higher than the corresponding seawater values (Figure 6f).

\section{Discussion}

The deepwater $\mathrm{Nd}$ isotopic compositions correlate with other water mass properties (Figures 3 and $4 \mathrm{abc}$ ) whereas shallower waters show the weaker relationships (Figure S2abc) 
with larger $\varepsilon_{\mathrm{Nd}}$ variability (Figure 2). Linear correlations between tracers indicate mixing if the tracer is conservative. Linear relationships with non-conservative tracers (i.e. nutrients) suggest that whatever mechanisms control one variable are also likely the mechanisms that control the other. In modern deep waters, nutrient concentrations vary essentially with water mass mixing (Broecker and Peng, 1982). Almost linear relationships between deepwater $\varepsilon_{\mathrm{Nd}}$ values with hydrography parameters were already reported (Goldstein and Hemming, 2003; Piotrowski et al., 2008; Hu et al., 2016), which is consistent with our observation (Figures 3 and $4 \mathrm{abc}$ ). Our hypothesis here is that deepwater $\varepsilon_{\mathrm{Nd}}$ variability that is explained by linear relationships with hydrography parameters corresponds to the mixing of water masses of which $\varepsilon_{\mathrm{Nd}}$ values are distinct. Large offsets from the predicted values indicate that other processes than the ones governing the large-scale tracer evolution are at play. For the case of $\mathrm{Nd}$ isotopic compositions, we consider this to be a sign of significant local/regional influence.

\subsection{Empirical equations that predict deepwater $\varepsilon_{\mathrm{Nd}}$ trends and evaluation of local/regional influence}

Applying multiple regression analysis to deep $(\geq 1500 \mathrm{~m})$ seawater data, we establish empirical equations that predict the main, large-scale, deepwater $\varepsilon_{\mathrm{Nd}}$ trends from hydrography parameters. We use hydrography data WOA09 (Antonov et al., 2010; Garcia et al., 2010a; Garcia et al., 2010b; Locarnini et al., 2010) because they are available for the major oceans with $1^{\circ}$ resolution and indicate a good agreement with values compiled in NEOSYMPA database (Figure S1).

For the modern global deep waters, nutrients and oxygen concentrations present a bimodal distribution with a peak corresponding to a nutrient-poor and oxygen-rich Atlantic water (except for the southernmost Atlantic) and another peak corresponding to deep waters of other oceanic regions with higher nutrient contents and more depleted oxygen (Figure S4). 
As a consequence, the Atlantic $\left(50^{\circ} \mathrm{S}\right.$ to $\left.75^{\circ} \mathrm{N}\right)$ is treated separately from the global ocean for multiple regression analysis. Only the variables showing a normal distribution (examined mainly with Kolmogorov-Smirnov/Lilliefor Test) are used for regression analysis. The number of variables is optimized based on Akaike's Information Criterion (Motulsky and Christopoulos, 2004) (Table S3ab). Data from restricted basins such as Caribbean Sea, Labrador Sea and Bay of Bengal are not considered for the regression analysis because of the $\varepsilon_{\mathrm{Nd}}$ values decoupled from the general trend (Figure 3).

Established empirical relationships for the Atlantic $\left(50^{\circ} \mathrm{S}\right.$ to $\left.75^{\circ} \mathrm{N}\right)$ and other global oceans are expressed by equations 1 and 2, respectively:

$$
\begin{aligned}
& \varepsilon_{\mathrm{Nd}}=-0.7372 \mathrm{~T}\left[{ }^{\circ} \mathrm{C}\right]-0.9385 \mathrm{O}_{2}[\mathrm{ml} / 1]-4.5207 \quad(\mathrm{r}=0.705) \\
& \varepsilon_{\mathrm{Nd}}=2.252 * \mathrm{PO}_{4}[\mu \mathrm{mol} / 1]+0.04635 * \mathrm{SiO}_{2}[\mu \mathrm{mol} / \mathrm{l}]-9.958 * \text { Salinity }+0.2861 * \mathrm{~T}\left[{ }^{\circ} \mathrm{C}\right] \\
& +326.95 \quad(\mathrm{r}=0.845)
\end{aligned}
$$

They are the first equations that allow calculating deepwater $\mathrm{Nd}$ isotopic compositions at $\geq$ $1500 \mathrm{~m}$. Figure 7 compares the predicted and observed deepwater $\varepsilon_{\mathrm{Nd}}$ values in the Atlantic and the Atlantic sector of the Southern Ocean (Figure 7ab), as well as the Indian, the Pacific and the Pacific sector of the Southern Ocean (Figure 7cd). Large-scale isotopic variation including the penetration and the extension of northern- and southern-sourced waters are well demonstrated in zonal-average meridional transect in both Atlantic and Pacific (Figure 7bd). These results confirm that the major deepwater $\mathrm{Nd}$ isotopic variation can be explained by the mixing of preformed tracers. However, there are some significant offsets between predicted and observed seawater $\mathrm{Nd}$ isotopic signatures in the eastern and western equatorial Pacific where the observed values are higher than the predicted $\mathrm{Nd}$ isotopic compositions (Figure 7cd). Also, predicted values for the MOW is anomaly low because of warmer temperature of this water mass (equation 1) relative to other Atlantic waters (not shown in figure). Except for this specific artifact, any systematic bias is noticed. The mean difference between observed 
and predicted $\varepsilon_{\mathrm{Nd}}$ values is almost zero (Figure 8) and residual values present a normal distribution (Figure 8). The global performance of the multiple regression analysis is shown in Figure 8.

We now define that significant local/regional detrital influence by a difference between observed and predicted $\varepsilon_{\mathrm{Nd}}$ values, $\varepsilon_{\mathrm{Nd}}($ observed-predicted). The values out of range of $2 \sigma$ (Figure 8 ) is considered as a sign of local/regional detrital influence, which corresponds roughly to $\varepsilon_{\mathrm{Nd}}$ (observed-predicted) values $<+2 \varepsilon$-units or $>-2 \varepsilon$-units (Figure 8$)$. The predicted $\varepsilon_{\mathrm{Nd}}$ values, the difference between measured and predicted isotopic composition, as well as judgment about significant local/regional influence are all listed in Table S1.

\subsection{Spatial distribution of sites affected by local/regional detrital inputs}

The distribution of sites with significant local/regional influence on seawater $\varepsilon_{\mathrm{Nd}}$ values (Figure 9a) is generally consistent with the estimation based on multi-scatter plots (Figure 4abc). The regression results allow identifying more detail, in particular for the Indian Ocean where the poor spatial coverage of data prevents from establishing general mixing trends (Figure 4b). Applying the same criteria of local/regional effects as the seawater samples to archive $\varepsilon_{\mathrm{Nd}}$ data, the distribution of locally affected archive sites is determined (Figure 9c). Again, it generally agrees with the results of multi-scatter plots (Figure 5abc). It is worth noting that there exists certain similarity of locations between the seawater and archive sites affected by local/regional influence, for instance the Eastern Equatorial Pacific (labeled "a" in Figure 9ac), around Hawaii ("b" in Figure 9ac) and close to Iceland ("c" in Figure 9ac) with positive $\varepsilon_{\mathrm{Nd}}$ offsets, and Bay of Bengal ("d" in Figure 9ac) and central North Pacific ("e" in Figure 9ac) with negative bias. The positive offsets observed for the western equatorial Pacific seawater in Figure 7c do not appear in Figure 8a because the nutrient data for these coastal sites are not available, which prevents the application of equation 2 . 
The relationships between the water depths and the distance from the margins reveal that the main detrital impact occurs roughly within 1,000 km from the margins (Figure 9bd). For seawater samples, 61 data are evaluated to be affected by local/regional effects, and 57 data are from the sites within $1,000 \mathrm{~km}$ from the margins, which corresponds to $93 \%$. Totally 195 archive data are estimated to be influenced by detrital inputs, and 179 data (92\%) are from sites within 1,000km from the margins. Several seawater samples (labeled "fo" and "g" in Figure 9ac) show the offsets far from the continental margins. At station GYR in the Southeastern Pacific ("fo' in Figure 9ab), the radiogenic seawater Nd signature was explained by ridge exchange above the East Pacific Rise (Jeandel et al., 2013). Similarly, the positive offset in the South Atlantic (station S4, "g" in Figure 9ac) may reflect the influence of radiogenic Mid Atlantic Ridge although the contribution of the South American shelf sediments and of the Antarctic Peninsula sediments could not be discarded (Garcia-Solsona et al., 2014).

The archives present more frequently positive offsets than negative ones (Figure 9cd). There are two ways of explaining this feature. Firstly, the dissolution of labile detrital $\mathrm{Nd}$ during leaching procedures could produce such biases (Elmore et al., 2011; Piotrowski et al., 2012; Ehlert et al., 2013; Kraft et al., 2013; Wu et al., 2015b) and consequently the observed offsets could be an artifact. Secondly the archive $\varepsilon_{\mathrm{Nd}}$ values reflect pore water $\mathrm{Nd}$ signals that are more radiogenic than the overlying bottom waters (Wilson et al., 2013; Abbott et al., 2015; Molina-Kescher, 2015; Wu et al., 2015b; Blaser et al., 2016; Du et al., 2016). Both explanations are plausible, and the prevailing reason may vary with regions. It is also possible that some archive $\varepsilon_{\mathrm{Nd}}$ offsets reflect the real temporal variation of deepwater $\varepsilon_{\mathrm{Nd}}$ values. In fact, some mid- or early Holocene data indicate significant difference from the predicted modern seawater values (Figure S5). At this stage it is difficult to compare the faithfulness of different archives since data number and sampling locations strongly vary with archive types 
(Figures 1 and S5). Nonetheless, we tentatively suggest that the $\mathrm{HH}$ leachate with decarbonation tends to be more frequently biased (Figure S5, see also section 4.4).

\subsection{Possible processes modulating local/regional detrital inputs}

Possible provenance of detrital inputs can be deduced from the $\mathrm{Nd}$ isotopic composition. In general, the difference between observed and predicted seawater $\varepsilon_{\mathrm{Nd}}$ values is positive for the circum Pacific and negative in the Labrador Sea and the Bay of Bengal (Figure 8). This geographical trends is consistent with the Nd isotopic signature of continental margins (Jeandel et al., 2007). In addition, the influence of remote dust source may have influence as suggested by negative offsets at around $30^{\circ} \mathrm{N}$ in the Pacific (Figure 9a) that underlies loess dust plume (Maher et al., 2010). The effective influence of detrital inputs depends on relative strength between physical water mass mixing and dissolved/particulate interaction (Roy-Barman et al., 2009; Osborne et al., 2015), stock of exchangeable $\mathrm{Nd}$ in particulate phases, as well as the contrast of $\mathrm{Nd}$ isotopic signature between dissolved and particulate phases.

The strong local effects close to the continental margins can be explained by the proximity of the sources as well as high detrital and biogenic particle concentrations in the water column that can promote reversible scavenging. A leading role of particulate phases as a vertical vector is further confirmed by another particle reactive tracer, Th isotopes with a recent GEOTRACES study in the North Atlantic (Lerner et al., 2016 and references therein). Indeed, coupled measurements of $\mathrm{Ra}$ and $\mathrm{Nd}$ isotopes as well as shale-normalized $\mathrm{REE}$ patterns on seawater samples from sites close to Hawaii demonstrate that radiogenic Nd from volcanic islands has a strong influence on surface water isotopic signature, and that the radiogenic $\mathrm{Nd}$ signal is vertically transported by dissolved/particulate interaction (Fröllje et al., 2016). In contrast, seasonally variable dust contribution is of secondary importance but 
affects significantly the surface waters (Fröllje et al., 2016). This observation is consistent with the results of the Northeastern Atlantic under the influence of Saharan dust (Stichel et al., 2015). Seasonal or annual variability of surface water Nd isotopic compositions may exist in relation to variable dissolved and particulate river and dust inputs as well as current reversal according to monsoon regime. Massive particle inputs could release exchangeable $\mathrm{Nd}$ in the water column and on seafloor (e.g. Bay of Bengal and at around $30^{\circ} \mathrm{N}$ in the North Pacific). Such processes could explain partly why certain margins show more important local/regional influences than others do (Figure 8a).

In addition to the $\mathrm{Nd}$ from the surface layer, benthic flux of $\mathrm{Nd}$ from coastal regions may contribute to the observed local influences (Abbott et al., 2015; Du et al., 2016; Abbott et al., 2016). The redox cycle during early diagenesis is active in shallow margin sediments because high organic matter content induces reducing pore water conditions. Pore water $\mathrm{Nd}$ concentration is tightly linked to Fe and Mn cycle (Elderfield and Sholkovitz, 1987; Haley et al., 2004). Under reduced pore water conditions, scavenged $\mathrm{Nd}$ can be released and labile detrital fractions can be dissolved, leading to discrepancy between bottom and pore water $\mathrm{Nd}$ isotopic signature if the isotopic composition of the reactive phases in sediments is different from the bottom water value. Indeed, large positive offsets from the predicted values are observed for both seawater and archive $\mathrm{Nd}$ isotopic signatures in the Eastern Equatorial Pacific, one of the regions where total organic carbon content in sediments is the highest in the modern ocean (Seiter et al., 2004).

Fresh river particles and poorly chemically weathered detrital material could be an additional Nd source to the oceans because they may contain exchangeable Nd (Sholkovitz, 1992; Singh et al., 2012; Roberts and Piotrowski, 2015; Rousseau et al., 2015; Howe et al., 2016b). The impact of poorly chemically weathered detrital material was originally proposed for unradiogenic $\varepsilon_{\mathrm{Nd}}$ values extracted from foraminiferal tests that reflects weathered detrital 
material due to the retreat of Laurentide ice sheet during deglaciation (Howe et al., 2016b). In addition to the redox changes that create a benthic flux, transformation of meta-stable minerals containing $\mathrm{Nd}$ into stable minerals in contact with seawater produces isotopic exchange on time scales from weeks to months (Jeandel et al., 2011; Jones et al., 2012; Jeandel and Oelkers, 2015).

All these processes participate in the determination of local/regional effects in a distinct manner according to different regions, which makes it difficult to provide precise meaning for the observed distance and water depths. Further insight would be obtained by coupling Nd isotopes, REE patterns and modeling approaches (Oka et al., 2009; Chen et al., 2013a; Zheng et al., 2016). Our results do not provide clear evidence for the impact of oxygen minimum zones (OMZ) on Nd isotopic variability, similarly to the previous study (Jeandel et al., 2013). Subtle variability related to the reduction of Fe-Mn oxides and consequent release of $\mathrm{Nd}$ in $\mathrm{OMZ}$ might be quantified for different $\mathrm{OMZ}$ by coupled $\mathrm{Nd}$ isotopes and REE patterns (Zheng et al., 2016).

\subsection{Nd isotopic ratio as a paleo-circulation tracer}

The global thermohaline circulation controls the transport of heat, water, salt and nutrients, and affects the segregation of carbon between the atmosphere and the ocean. The $\mathrm{Nd}$ isotopes can evaluate the variable contribution between northern/southern-sourced water masses in relation to global thermohaline circulation states (Friedrich et al., 2014). We examine latitudinal seawater and archive $\varepsilon_{\mathrm{Nd}}$ variability for the Atlantic, the Pacific and the Southern Ocean at intermediate and deep water depths $(\geq 600 \mathrm{~m})$ after the removal of deep water data significantly influenced by local/regional effects (Figure 10abcd). Since quantitative evaluation of the detrital influence on waters at $<1500 \mathrm{~m}$ is not available, the whole intermediate water data are considered. 
The Atlantic, Pacific and corresponding sectors in the Southern Ocean indicate clear latitudinal trends for seawater and archive $\mathrm{Nd}$ isotopic compositions. We note that the $\varepsilon_{\mathrm{Nd}}$ values of four archive data sets at intermediate water depths (labeled "i" to "iv" in Figure 10bd) are more than $2 \varepsilon$-units different from the corresponding seawater values. They are all $\mathrm{HH}$ leachates with decarbonation. The lower $\varepsilon_{\mathrm{Nd}}$ values off Niger River mouth (labeled "i" in Figure 10b) possibly reflect unradiogenic signals of preformed Fe-Mn oxides (Kraft et al., 2013). Since the higher $\varepsilon_{\mathrm{Nd}}$ values for Brazil margin correspond to early Holocene (labeled "ii" in Figure 10b), they could correspond to the real temporal variability (Pahnke et al., 2008). The $\mathrm{HH}$ leachate of Antarctic sediment of which the detrital fraction is as high as -2.7 shows a strong positive offset (labeled "iii" in Figure 10d) (Carter et al., 2012). Finally, the archive $\varepsilon_{\mathrm{Nd}}$ data from the South-eastern Pacific (labeled "iv" in Figure 10d) allow comparing the performance of different archives because foraminiferal authigenic oxides, HH leachates with or without decarbonation were obtained from the same sediments (Molina-Kescher et al., 2014). The $\mathrm{Nd}$ isotopic compositions of foraminiferal oxides and $\mathrm{HH}$ leachate without decarbonation fall on the general latitudinal trend formed by seawater data, further confirm the preference to omit the decarbonation step.

The clear latitudinal gradients attest the usefulness of $\mathrm{Nd}$ isotopes to evaluate the variability in northern and southern origin water proportion in relation to global circulation changes when the sites are not under strong local/regional continental inputs, supporting the application of this tracer to modern and paleo-oceanography studies.

\section{Conclusions}

A new global database of seawater and archive $\mathrm{Nd}$ isotopic compositions was constructed and combined with hydrography parameters (temperature, salinity, nutrient and oxygen concentrations), $\delta^{13} \mathrm{C}$ and $\Delta{ }^{14} \mathrm{C}$ values of dissolved inorganic carbon. Archive $\varepsilon_{\mathrm{Nd}}$ data 
correspond to various leachates, foraminiferal tests, deep-sea corals and fish teeth/debris from the Holocene period $(<10,000$ years). Using property-property (multi-scatter) plots and T-S$\varepsilon_{\mathrm{Nd}}$ diagrams, we examined the correspondence between the seawater and archive $\mathrm{Nd}$ isotopic compositions.

At water depths $\geq 1500 \mathrm{~m}$, multi-scatter plots present clear correlations between seawater $\varepsilon_{\mathrm{Nd}}$ and the other water mass indicators whereas at 600-1500m water depths, the relationships are weaker. Basin-scale seawater vertical $\varepsilon_{\mathrm{Nd}}$ profiles demonstrate larger variability at surface and subsurface depths, suggesting local/regional detrital influence at shallower water depths.

Basin-scale seawater T-S- $\varepsilon_{\mathrm{Nd}}$ diagrams allow associating Nd isotopic compositions with water masses. One of the most striking features is radiogenic seawater Nd isotopic composition for surface and intermediate water masses in tropical Pacific that cannot be explained by only water mass mixing.

Archival $\mathrm{Nd}$ isotopic compositions generally agree with corresponding seawater values although they tend to be at the upper limit in the Pacific and both positive and negative offsets exist in the northern North Atlantic.

Applying multiple regression analysis to deep $(\geq 1500 \mathrm{~m})$ seawater data, we established empirical equations that predict the main, large-scale, deepwater $\varepsilon_{\mathrm{Nd}}$ trends from hydrography parameters. Large offsets from the predicted values are interpreted as a sign of significant local/regional influence. Dominant detrital influences are observed mainly within $1,000 \mathrm{~km}$ from the continents. Archive data show more frequently positive offsets that may indicate radiogenic $\mathrm{Nd}$ contribution from labile detrital fraction to pore water and/or by chemical extraction of authigenic phases. HH leachate with decarbonation at certain sites present larger offsets from the predicted seawater values than foraminiferal oxides and $\mathrm{HH}$ leachate without decarbonation. 
Except data influenced by local/regional detrital effects, seawater and archive $\varepsilon_{\mathrm{Nd}}$ values present clear latitudinal trends in the Atlantic and Pacific at water depths $\geq 600 \mathrm{~m}$, consistent with the idea that $\mathrm{Nd}$ isotopes help distinguish between northern/southern sourced water contributions at intermediate and deep water depths in the present and past ocean.

\section{Acknowledgement}

This work was supported by NEOSYMPA project (CYBER/LEFE) granted to KT. We thank l'OSU-Institut Pythéas for technical support of data extraction program. Norbert Frank further received support from the German Science Foundation through the project DFGNEOGLACIAL (FR-1341/3-1 and 3-2). We thank Brian Haley for helpful suggestions. Thibault de Garidel-Thoron is thanked for the initiation of ODV for KT.

Figure caption

Figure 1. Location map of all stations with $\varepsilon_{\mathrm{Nd}}$ data together with vertical distribution of seawater and archives data stations. Black dots indicate seawater stations whereas open circles show various archive stations with color code. The map is visualized using the software Ocean Data View (ODV) (Schlitzer, 2015).

Figure 2. Depth profiles of the compiled data in different oceanic basins. Seawater $\mathrm{Nd}$ concentrations (upper panels), seawater $\varepsilon_{\mathrm{Nd}}$ values (middle panels), and archive $\varepsilon_{\mathrm{Nd}}$ values (lower panels) for the Atlantic, Southern Ocean, Indian and Pacific. The color code indicates the latitudes of the data stations. The profiles are created using ODV (Schlitzer, 2015).

Figure 3. Seawater multi-scatter plots for data at water depths deeper than $1500 \mathrm{~m}$ in the Atlantic, Southern Ocean, Indian and Pacific. All the data to create the plots are compiled in 
NEOSYMPA database. The numbers on the map show the area where seawater $\varepsilon_{\mathrm{Nd}}$ values are offset from the general trend (see text for detail). The figures and the map are created using ODV (Schlitzer, 2015).

Figure 4. Seawater property-property plots for water depths deeper than $1500 \mathrm{~m}$. The color code shows latitudes (a and c) or longitude (b) of data stations. a) Atlantic and Atlantic sector of the Southern Ocean, b) Indian, and c) Pacific and Pacific sector of the Southern Ocean. MOW=Mediterranean Outflow Water. The numbers on the maps show the sites where seawater $\varepsilon_{\mathrm{Nd}}$ values are offset from the general trend (see text for detail). The figures and the maps are created using ODV (Schlitzer, 2015).

Figure 5. Basin-scale archive multi-scatter plots at $\geq 1500 \mathrm{~m}$. a) Atlantic, b) Indian, and c) Pacific and Pacific sector of the Southern Ocean. The red and bleu stations on the maps indicate the sites with positive and negative offsets, respectively. The color code shows different archive types and gray dots indicate seawater values shown in Figure 4abc. There is no archive data from deepwater depths $(\geq 1500 \mathrm{~m})$ in the Atlantic and Indian sectors of the Southern Ocean. The numbers on the map show the area where seawater $\varepsilon_{\mathrm{Nd}}$ values are offset from the general trend (see text for detail). The figures and the maps are created using ODV (Schlitzer, 2015).

Figure 6. Atlantic, Indian and Pacific $\mathrm{T}-\mathrm{S}-\varepsilon_{\mathrm{Nd}}$ diagrams for seawater $(\mathrm{a}, \mathrm{c}, \mathrm{e})$ and archives $(\mathrm{b}$, d, f) at water depths from $200 \mathrm{~m}$ to bottom. Mean seawater $\varepsilon_{\mathrm{Nd}}$ values of major water masses are summarized in Table 1, and the temperature and salinity ranges and the geographical extension of the water masses are shown in Table S2 (Emery and Meincke, 1986; Amakawa 
et al., 2009; Bostock et al., 2013). The figures and the maps are created using ODV (Schlitzer, 2015).

Figure 7. Comparison between predicted deepwater $\varepsilon_{\mathrm{Nd}}$ values (background color) with equation 1 (Atlantic at $50^{\circ} \mathrm{S}$ to $75^{\circ} \mathrm{N}$ ) and equation 2 (global ocean except for the Atlantic at $50^{\circ} \mathrm{S}$ to $75^{\circ} \mathrm{N}$ ) with observed seawater $\varepsilon_{\mathrm{Nd}}$ values (color dots). The predicted deepwater $\varepsilon_{\mathrm{Nd}}$ values at $1500 \mathrm{~m}$ are compared with observed seawater $\varepsilon_{\mathrm{Nd}}$ values at $\geq 1500 \mathrm{~m}$ in the Atlantic and Atlantic sector of the Southern Ocean (a) and the other oceanic regions (c). Zonally averaged latitudinal transect at $1500-6000 \mathrm{~m}$ of the Atlantic (b) and the Pacific (d). Note that the $\varepsilon_{\mathrm{Nd}}$ scales are different with basins. The Atlantic sector of the Southern Ocean and the southernmost Atlantic $\left(75^{\circ} \mathrm{S}\right.$ to $\left.50^{\circ} \mathrm{S}\right)$ is treated as a buffer zone where deepwater $\varepsilon_{\mathrm{Nd}}$ values are calculated by both equations 1 and 2 , and weighted-averaged values considering latitudinal position are shown. All the figures and maps are created using ODV (Schlitzer, 2015).

Figure 8. Comparison between the predicted and observed global seawater $\varepsilon_{\mathrm{Nd}}$ values. Map showing the distribution of difference between observed and predicted $\varepsilon_{\mathrm{Nd}}$ values that correspond to -(residual $\varepsilon_{\mathrm{Nd}}$ ) values at $\geq 1500 \mathrm{~m}$ (upper left panel). Histogram of -(residual $\varepsilon_{\mathrm{Nd}}$ ) values with $2 \sigma$ interval (dashed lines, upper right panel). Scatter plots showing the correlation between observed and predicted $\varepsilon_{\mathrm{Nd}}$ values with latitude (lower left panel) or with oceanic basins (lower right panel). The figures and the map are created using ODV (Schlitzer, 2015).

Figure 9. Distribution of sites where the seawater and archive $\varepsilon_{\mathrm{Nd}}$ values are significantly affected by local/regional detrital inputs. Maps showing the sites at $\geq 1500 \mathrm{~m}$ for seawater 
data (a) and archive data (c). Relationship between the distance from margin and water depth for seawater data (b) and archive data (d). Labels "a" to "g" show sites discussed in the text. All the figures and maps are created using ODV (Schlitzer, 2015).

Figure 10. Latitudinal trends of seawater ( $\mathrm{a}$ and c) and archive (b and d) $\varepsilon_{\mathrm{Nd}}$ values in the Atlantic and Atlantic sector of the Southern Ocean at $75^{\circ} \mathrm{S}-60^{\circ} \mathrm{N}$ (a and b) and Pacific and Pacific sector of the Southern Ocean (c and d) at $\geq 600 \mathrm{~m}$ without deep water data significantly affected by local/regional effects. The color code indicates water depths. The major water masses are also shown (Table 1). The grey dots on archive figures (b and d) show seawater values. Labels (i) to (iv) indicate the archive data that are offset from the seawater trends (see text for detail). All the figures and maps are created using ODV (Schlitzer, 2015).

\section{References}

Abbott, A.N., Haley, B.A., McManus, J., 2015. Bottoms up: Sedimentary control of the deep North Pacific Ocean's \&Nd signature. Geology, 43(11): 1035.

Abbott, A.N., Haley, B.A., McManus, J., 2016. The impact of sedimentary coatings on the diagenetic Nd flux. Earth and Planetary Science Letters, 449: 217-227.

Achyuthan, H., Nagasundaram, M., Gourlan, A.T., Eastoe, C., Ahmad, S.M., Padmakumari, V.M., 2014. Mid-Holocene Indian Summer Monsoon variability off the Andaman Islands, Bay of Bengal. Quaternary International, 349: 232-244.

Albarède, F., Goldstein, S., 1992. A world map of Nd isotopes in seafloor ferromanganese deposits. Geology, 20: 761-763.

Amakawa, H., Alibo, D.S., Nozaki, Y., 2004. Nd concentration and isotopic composition distributions in surface waters of Northwest Pacific Ocean and its adjacent seas. Geochemical J., 38: 493-504.

Amakawa, H., Sasaki, K., Ebihara, M., 2009. Nd isotopic composition in the central North Pacific. Geochimica Et Cosmochimica Acta, 73(16): 4705-4719.

Amakawa, H., Tazoe, H., Obata, H., Gamo, T., Sano, Y., Shen, C.C., 2013. Neodymium isotopic composition and concentration in the Southwest Pacific Ocean. Geochemical Journal, 47: 409-422.

Antonov, J.I., Seidov, D., Boyer, T.P., Locarnini, R.A., Mishonov, A.V., Garcia, H.E., Baranova, O.K., Zweng, M.M., Johnson, D.R., 2010. World Ocean Atlas 2009, Volume 2: Salinity. In: Levitus, S. (Ed.), NOAA Atlas NESDIS 68. U.S. Government Printing Office, Washington, D.C., pp. 184.

Arsouze, T., Dutay, J.C., Lacan, F., Jeandel, C., 2007. Modeling the neodymium isotopic composition with a global ocean circulation model. Chem. Geology, 239(1-2): 165-177. 
Arsouze, T., Dutay, J.C., Lacan, F., Jeandel, C., 2009. Reconstructing the Nd oceanic cycle using a coupled dynamical ,Biogeochemical model. Biogeosciences, 6(12): 28292846.

Asahara, Y., Takeuchi, F., Nagashima, K., Harada, N., Yamamoto, K., Oguri, K., Tadai, O., 2012. Provenance of terrigenous detritus of the surface sediments in the Bering and Chukchi Seas as derived from Sr and Nd isotopes: Implications for recent climate change in the Arctic regions. Deep Sea Research Part II: Topical Studies in Oceanography, 61-64(0): 155-171.

Basak, C., Martin, E.E., Horikawa, K., Marchitto, T.M., 2010. Southern Ocean source of 14C-depleted carbon in the North Pacific Ocean during the last deglaciation. Nature Geosci, 3(11): 770-773.

Basak, C., Pahnke, K., Frank, M., Lamy, F., Gersonde, R., 2015. Neodymium isotopic characterization of Ross Sea Bottom Water and its advection through the southern South Pacific. Earth and Planetary Science Letters, 419(0): 211-221.

Bayon, G., Birot, D., Ruffine, L., Caprais, J.C., Ponzevera, E., Bollinger, C., Donval, J.P., Charlou, J.L., Voisset, M., Grimaud, S., 2011. Evidence for intense REE scavenging at cold seeps from the Niger Delta margin. Earth and Planetary Science Letters, 312(3-4): 443-452.

Bayon, G., German, C.R., Boella, R.M., Milton, J.A., Taylor, R.N., Nesbitt, R.W., 2002. An improved method for extracting marine sediment fractions and its application to Sr and Nd isotopic analysis. Chem. Geol., 187: 179-199.

Bayon, G., German, C.R., Burton, K.W., Nesbitt, R.W., Rogers, N., 2004. Sedimentary Fe-Mn oxyhydroxides as paleoceanographic archives and the role of aeolian flux in regulating oceanic dissolved REE. Earth and Planetary Science Letters, 224(3-4): 477-492.

Bertram, C.J., Elderfield, H., 1993. The geochemical balance of the rare earth elements and Nd isotopes in the oceans. Geochim. Cosmochim. Acta, 57: 1957-1986.

Blaser, P., Lippold, J., Gutjahr, M., Frank, N., Link, J.M., Frank, M., 2016. Extracting foraminiferal seawater $\mathrm{Nd}$ isotope signatures from bulk deep sea sediment by chemical leaching. Chemical Geology, 439: 189-204.

Bostock, H.C., Sutton, P.J., Williams, M.J.M., Opdyke, B.N., 2013. Reviewing the circulation and mixing of Antarctic Intermediate Water in the South Pacific using evidence from geochemical tracers and Argo float trajectories. Deep Sea Research Part I: Oceanographic Research Papers, 73(0): 84-98.

Bouvier, A., Vervoort, J.D., Patchett, P.J., 2008. The Lu-Hf and Sm-Nd isotopic composition of CHUR: Constraints from unequilibrated chondrites and implications for the bulk composition of terrestrial planets. Earth and Planetary Science Letters, 273(1-2): 48-57.

Broecker, W.S., Peng, T.H., 1982. Tracers in the Sea. Lamont-Doherty Geological Observatory, Columbia University, Palisades, 243 pp.

Burton, K.W., Vance, D., 2000. Glacial-interglacial variations in the neodymium isotope composition of seawater in the Bay of Bengal recorded by planktonic foraminifera. Earth and Planetary Science Letters, 176(3-4): 425-441.

Carter, P., Vance, D., Hillenbrand, C.D., Smith, J.A., Shoosmith, D.R., 2012. The neodymium isotopic composition of waters masses in the eastern Pacific sector of the Southern Ocean. Geochimica Et Cosmochimica Acta, 79(0): 41-59.

Charbonnier, G., Puceat, E., Bayon, G., Desmares, D., Dera, G., Durlet, C., Deconinck, J.-F., Amedro, F., Gourlan, A.T., Pellenard, P., Bomou, B., 2012. Reconstruction of the Nd isotope composition of seawater on epicontinental seas: Testing the potential of 
Fe-Mn oxyhydroxide coatings on foraminifera tests for deep-time investigations. Geochimica Et Cosmochimica Acta, 99(0): 39-56.

Chen, T.-Y., Frank, M., Haley, B.A., Gutjahr, M., Spielhagen, R.F., 2012. Variations of North Atlantic inflow to the central Arctic Ocean over the last 14 million years inferred from hafnium and neodymium isotopes. Earth and Planetary Science Letters, 353-354(0): 82-92.

Chen, T.-Y., Rempfer, J., Frank, M., Stumpf, R., Molina-Kescher, M., 2013a. Upper ocean vertical supply: A neglected primary factor controlling the distribution of neodymium concentrations of open ocean surface waters? Journal of Geophysical Research: Oceans, 118(8): 3887-3894.

Chen, T.-Y., Stumpf, R., Frank, M., Bełdowski, J., Staubwasser, M., 2013b. Contrasting geochemical cycling of hafnium and neodymium in the central Baltic Sea. Geochimica et Cosmochimica Acta, 123(0): 166-180.

Colin, C., Frank, N., Copard, K., Douville, E., 2010. Neodymium isotopic composition of deep-sea corals from the NE Atlantic: implications for past hydrological changes during the Holocene. Quaternary Science Reviews, 29(19-20): 2509-2517.

Copard, K., Colin, C., Douville, E., Freiwald, A., Gudmundsson, G., De Mol, B., Frank, N., 2010. Nd isotopes in deep-sea corals in the North-eastern Atlantic. Quaternary Science Reviews, 29(19-20): 2499-2508.

Copard, K., Colin, C., Frank, N., Jeandel, C., Montero-Serrano, J.C., Reverdin, G., Ferron, B., 2011. Nd isotopic composition of water masses and dilution of the Mediterranean outflow along the southwest European margin. Geochem. Geophys. Geosyst., 12(6): Q06020.

Copard, K., Colin, C., Henderson, G.M., Scholten, J., Douville, E., Sicre, M.A., Frank, N., 2012. Late Holocene intermediate water variability in the northeastern Atlantic as recorded by deep-sea corals. Earth and Planetary Science Letters, 313-314(0): 34-44.

Crocket, K.C., Vance, D., Gutjahr, M., Foster, G.L., Richards, D.A., 2011. Persistent Nordic deep-water overflow to the glacial North Atlantic. Geology, 39(6): 515-518.

Dera, G., Puceat, E., Pellenard, P., Neige, P., Delsate, D., Joachimski, M.M., Reisberg, L., Martinez, M., 2009. Water mass exchange and variations in seawater temperature in the NW Tethys during the Early Jurassic: Evidence from neodymium and oxygen isotopes of fish teeth and belemnites. Earth and Planetary Science Letters, 286(1-2): 198-207.

Du, J., Haley, B.A., Mix, A.C., 2016. Neodymium isotopes in authigenic phases, bottom waters and detrital sediments in the Gulf of Alaska and their implications for paleo-circulation reconstruction. Geochimica et Cosmochimica Acta, 193: 14-35.

Dubois-Dauphin, Q., Bonneau, L., Colin, C., Montero-Serrano, J.-C., Montagna, P., Blamart, D., Hebbeln, D., Van Rooij, D., Pons-Branchu, E., Hemsing, F., Wefing, A.-M., Frank, N., 2016a. South Atlantic intermediate water advances into the North-east Atlantic with reduced Atlantic meridional overturning circulation during the last glacial period. Geochemistry, Geophysics, Geosystems, 17(6): 2336-2353.

Dubois-Dauphin, Q., Colin, C., Bonneau, L., Montagna, P., Wu, Q., Van Rooij, D., Reverdin, G., Douville, E., Thil, F., Waldner, A., Frank, N., submitted. Fingerprinting Northeast Atlantic water masses using Neodymium isotopes. Geochim. Cosmochi. Acta.

Dubois-Dauphin, Q., Montagna, P., Siani, G., Douville, E., Wienberg, C., Hebbeln, D., Liu, Z., Kallel, N., Dapoigny, A., Revel, M., Pons-Branchu, E., Colin, C., 2016b. Hydrological variations of the intermediate water masses of the western Mediterranean Sea 
during the past 20 ka inferred from neodymium isotopic composition in foraminifera and cold-water corals. Clim. Past Discuss., 2016: 1-36.

Ehlert, C., Grasse, P., Frank, M., 2013. Changes in silicate utilisation and upwelling intensity off Peru since the Last Glacial Maximum -insights from silicon and neodymium isotopes. Quaternary Science Reviews, 72(0): 18-35.

Elderfield, H., Sholkovitz, E.R., 1987. Rare earth elements in the pore waters of reducing nearshore sediments. Earth and Planet. Sci. Lett., 82: 280-288.

Elmore, A.C., Piotrowski, A.M., Wright, J.D., Scrivner, A.E., 2011. Testing the extraction of past seawater $\mathrm{Nd}$ isotopic composition from North Atlantic deep sea sediments and foraminifera. Geochem. Geophys. Geosyst., 12(9): Q09008.

Elmore, A.C., Wright, J.D., 2011. North Atlantic Deep Water and climate variability during the Younger Dryas cold period. Geology, 39(2): 107-110.

Emery, W.J., Meincke, J., 1986. Global water masses: summary and review. Oceanol. Acta, 9(4): 383-391.

Frank, M., 2002. Radiogenic isotopes: Tracers of past ocean circulation and erosional input. Rev. Geophys . 40(1): 1001, doi : 10.1029/2000RG000094.

Frank, N., Freiwald, A., Correa, M.L., Wienberg, C., Eisele, M., Hebbeln, D., Van Rooij, D., Henriet, J.-P., Colin, C., van Weering, T., de Haas, H., Buhl-Mortensen, P., Roberts, J.M., De Mol, B., Douville, E., Blamart, D., Hatté, C., 2011. Northeastern Atlantic cold-water coral reefs and climate. Geology, 39(8): 743-746.

Freslon, N., Bayon, G., Toucanne, S., Bermell, S., Bollinger, C., Chéron, S., Etoubleau, J., Germain, Y., Khripounoff, A., Ponzevera, E., Rouget, M.-L., 2014. Rare earth elements and neodymium isotopes in sedimentary organic matter. Geochimica et Cosmochimica Acta, 140(0): 177-198.

Freydier, R., Michard, A., De Lange, G.J., Thomson, J., 2001. Nd isotopic compositions of Eastern Mediterranean sediments: tracers of the Nile influence on sapropel S1 formation. Mar. Geol., 177(1-2): 45-62.

Friedrich, T., Timmermann, A., Stichel, T., Pahnke, K., 2014. Ocean circulation reconstructions from $\varepsilon N d$ : A model-based feasibility study. Paleoceanography, 29(11): 1003-1023.

Fröllje, H., Pahnke, K., Schnetger, B., Brumsack, H.-J., Dulai, H., Fitzsimmons, J.N., 2016. Hawaiian imprint on dissolved $\mathrm{Nd}$ and Ra isotopes and rare earth elements in the central North Pacific: Local survey and seasonal variability. Geochimica et Cosmochimica Acta, 189: 110-131.

Garcia, H.E., Locarnini, R.A., Boyer, T.P., Antonov, J.I., Baranova, O.K., Zweng, M.M., Johnson, D.R., 2010a. World Ocean Atlas 2009, Volume 3: Dissolved Oxygen, Apparent Oxygen Utilization, and Oxygen Saturation. In: Levitus, S. (Ed.), NOAA Atlas NESDIS 70. U.S. Government Printing Office, Washington, D.C., pp. 344.

Garcia, H.E., Locarnini, R.A., Boyer, T.P., Antonov, J.I., Zweng, M.M., Baranova, O.K., Johnson, D.R., 2010b. World Ocean Atlas 2009, Volume 4: Nutrients (phosphate, nitrate, silicate). In: Levitus, S. (Ed.), NOAA Atlas NESDIS 70. U.S. Government Printing Office, Washington, D.C., pp. 398.

Garcia-Solsona, E., Jeandel, C., Labatut, M., Lacan, F., Vance, D., Chavagnac, V., Pradoux, C., 2014. Rare earth elements and $\mathrm{Nd}$ isotopes tracing water mass mixing and particle-seawater interactions in the SE Atlantic. Geochimica et Cosmochimica Acta, 125(0): 351-372.

Goldstein, S., Hemming, S.R., 2003. Long lived Isotopic Tracers in Oceanography, Paleoceanography, and Ice sheet dynamics. Treatise on Geochemistry. Isevier Pergamon press, Amsterdam. 
Goswami, V., Singh, S.K., Bhushan, R., 2014. Impact of water mass mixing and dust deposition on $\mathrm{Nd}$ concentration and $\varepsilon \mathrm{Nd}$ of the Arabian Sea water column. Geochimica et Cosmochimica Acta, 145: 30-49.

Gourlan, A.T., Meynadier, L., Allègre, C.J., 2008. Tectonically driven changes in the Indian Ocean circulation over the last 25 Ma: Neodymium isotope evidence. Earth Planet. Sci. Lett., 267: 353-364.

Gourlan, A.T., Meynadier, L., Allegre, C.J., Tapponnier, P., Birck, J.-L., Joron, J.-L., 2010. Northern Hemisphere climate control of the Bengali rivers discharge during the past 4 Ma. Quaternary Science Reviews, 29(19-20): 2484-2498.

Grasse, P., Stichel, T., Stumpf, R., Stramma, L., Frank, M., 2012. The distribution of neodymium isotopes and concentrations in the Eastern Equatorial Pacific: Water mass advection versus particle exchange. Earth and Planetary Science Letters, 353-354(0): 198-207.

Grenier, M., Cravatte, S., Blanke, B., Menkes, C., Koch-Larrouy, A., Durand, F., Melet, A., Jeandel, C., 2011. From the western boundary currents to the Pacific Equatorial Undercurrent: Modeled pathways and water mass evolutions. J. Geophys. Res., 116(C12): C12044.

Grenier, M., Jeandel, C., Cravatte, S., 2014. From the subtropics to the equator in the Southwest Pacific: Continental material fluxes quantified using neodymium data along modeled thermocline water pathways. Journal of Geophysical Research: Oceans, 119(6): 3948-3966.

Grenier, M., Jeandel, C., Lacan, F., Vance, D., Venchiarutti, C., Cros, A., Cravatte, S., 2013. From the subtropics to the central equatorial Pacific Ocean: Neodymium isotopic composition and rare earth element concentration variations. Journal of Geophysical Research: Oceans, 118(2): 592-618.

Gutjahr, M., Frank, M., Stirling, C.H., Keigwin, L.D., Halliday, A.N., 2008. Tracing the Nd isotope evolution of North Atlantic Deep and Intermediate Waters in the western North Atlantic since the Last Glacial Maximum from Blake Ridge sediments. Earth and Planetary Science Letters, 266(1-2): 61-77.

Gutjahr, M., Frank, M., Stirling, C.H., Klemm, V., van de Flierdt, T., Halliday, A.N., 2007. Reliable extraction of a deepwater trace metal isotope signal from Fe-Mn oxyhydroxide coatings of marine sediments. Chemical Geology, 242(3-4): 351370.

Gutjahr, M., Lippold, J., 2011. Early arrival of Southern Source Water in the deep North Atlantic prior to Heinrich event 2. Paleoceanography, 26(2): PA2101.

Haley, B.A., Frank, M., Hathorne, E., Pisias, N., 2014. Biogeochemical implications from dissolved rare earth element and Nd isotope distributions in the Gulf of Alaska. Geochimica et Cosmochimica Acta, 126(0): 455-474.

Haley, B.A., Frank, M., Spielhagen, R.F., Eisenhauer, A., 2008a. Influence of brine formation on Arctic Ocean circulation over the past 15 million years. Nature Geosci, 1(1): 68-72.

Haley, B.A., Frank, M., Spielhagen, R.F., Fietzke, J., 2008b. Radiogenic isotope record of Arctic Ocean circulation and weathering inputs of the past 15 million years. Paleoceanography, 23(1): PA1S13.

Haley, B.A., Klinkhammer, G.P., McManus, J., 2004. Rare earth elements in pore waters of marine sediments. Geochimica Et Cosmochimica Acta, 68(6): 1265-1279.

Haley, B.A., Polyak, L., 2013. Pre-modern Arctic Ocean circulation from surface sediment neodymium isotopes. Geophysical Research Letters, 40(5): 893-897. 
Horikawa, K., Martin, E.E., Asahara, Y., Sagawa, T., 2011. Limits on conservative behavior of $\mathrm{Nd}$ isotopes in seawater assessed from analysis of fish teeth from Pacific core tops. Earth and Planetary Science Letters, 310(1-2): 119-130.

Howe, J.N.W., Piotrowski, A.M., Noble, T.L., Mulitza, S., Chiessi, C.M., Bayon, G., 2016a. North Atlantic Deep Water Production during the Last Glacial Maximum. Nature Communications, 7: 11765.

Howe, J.N.W., Piotrowski, A.M., Rennie, V.C.F., 2016b. Abyssal origin for the early Holocene pulse of unradiogenic neodymium isotopes in Atlantic seawater. Geology.

Hu, R., Piotrowski, A.M., Bostock, H.C., Crowhurst, S., Rennie, V., 2016. Variability of neodymium isotopes associated with planktonic foraminifera in the Pacific Ocean during the Holocene and Last Glacial Maximum. Earth and Planetary Science Letters, 447: 130-138.

Huang, K.-F., Oppo, D.W., Curry, W.B., 2014. Decreased influence of Antarctic intermediate water in the tropical Atlantic during North Atlantic cold events. Earth and Planetary Science Letters, 389(0): 200-208.

Jacobsen, S.B., Wasserburg, G.J., 1980. Sm-Nd isotopic evolution of chondrites. Earth Plan. Sci. Lett., 50: 139-155.

Jang, K., Han, Y., Huh, Y., Nam, S.-I., Stein, R., Mackensen, A., Matthiessen, J., 2013. Glacial freshwater discharge events recorded by authigenic neodymium isotopes in sediments from the Mendeleev Ridge, western Arctic Ocean. Earth and Planetary Science Letters, 369-370(0): 148-157.

Jeandel, C., 2016. Overview of the mechanisms that could explain the 'Boundary Exchange' at the land-ocean contact. Philosophical Transactions of the Royal Society A: Mathematical, Physical and Engineering Sciences, 374(2081).

Jeandel, C., Arsouze, T., Lacan, F., Téchine, P., Dutay, J.-C., 2007. Isotopic Nd compositions and concentrations of the lithogenic inputs into the ocean: A compilation, with an emphasis on the margins. Chem. Geol., 239: 156-164.

Jeandel, C., Bishop, J.K., Zindler, A., 1995. Exchange of $\mathrm{Nd}$ and its isotopes between seawater small and large particles in the Sargasso Sea. Geochim. Cosmochim. Acta, 59: 535-547.

Jeandel, C., Delattre, H., Grenier, M., Pradoux, C., Lacan, F., 2013. Rare earth element concentrations and $\mathrm{Nd}$ isotopes in the Southeast Pacific Ocean. Geochemistry, Geophysics, Geosystems, 14(2): 328-341.

Jeandel, C., Oelkers, E.H., 2015. The influence of terrigenous particulate material dissolution on ocean chemistry and global element cycles. Chemical Geology, 395(0): 50-66.

Jeandel, C., Peucker Ehrenbrink, B., Jones, M., Pearce, C., Oelkers, E., Godderis, Y., Lacan, F., Aumont, O., Arsouze, T., 2011. Ocean margins: the missing term for oceanic element budgets? . EOS, 92: 217-219.

Jeandel, C., Thouron, D., Fieux, M., 1998. Concentrations and isotopic compositions of Nd in the eastern Indian Ocean and Indonesian Straits. Geochim. Cosmochim. Acta, 62: 2597-2607.

Jiménez-Amat, P., Zahn, R., 2015. Offset timing of climate oscillations during the last two glacial-interglacial transitions connected with large-scale freshwater perturbation. Paleoceanography, 30(6): 768-788. 
Johannesson, K.H., Burdige, D.J., 2007. Balancing the global oceanic neodymium budget: Evaluating the role of groundwater. Earth and Planetary Science Letters, 253(12): 129-142.

Jones, K.M., Khatiwala, S.P., Goldstein, S.L., Hemming, S.R., van de Flierdt, T., 2008. Modeling the distribution of $\mathrm{Nd}$ isotopes in the oceans using an ocean general circulation model. Earth and Planetary Science Letters, 272(3-4): 610-619.

Jones, M.T., Pearce, C.R., Jeandel, C., Gislason, S.R., Eiriksdottir, E.S., Mavromatis, V., Oelkers, E.H., 2012. Riverine particulate material dissolution as a significant flux of strontium to the oceans. Earth and Planetary Science Letters, 355-356(0): 5159.

Jonkers, L., Zahn, R., Thomas, A., Henderson, G., Abouchami, W., François, R., Masque, P., Hall, I.R., Bickert, T., 2015. Deep circulation changes in the central South Atlantic during the past 145 kyrs reflected in a combined 231Pa/230Th, Neodymium isotope and benthic record. Earth and Planetary Science Letters, 419(0): 14-21.

Key, R.M., Kozyr, A., Sabine, C.L., Lee, K., Wanninkhof, R., Bullister, J.L., Feely, R.A., Millero, F.J., Mordy, C., Peng, T.H., 2004. A global ocean carbon climatology: Results from Global Data Analysis Project (GLODAP). Global Biogeochem. Cycles, 18(4): GB4031.

Klevenz, V., Vance, D., Schmidt, D.N., Mezger, K., 2008. Neodymium isotopes in benthic foraminifera: Core-top systematics and a down-core record from the Neogene south Atlantic. Earth and Planetary Science Letters, 265(3-4): 571-587.

Kraft, S., Frank, M., Hathorne, E.C., Weldeab, S., 2013. Assessment of seawater Nd isotope signatures extracted from foraminiferal shells and authigenic phases of Gulf of Guinea sediments. Geochimica et Cosmochimica Acta, 121(0): 414-435.

Lacan, F., Jeandel, C., 2001. Tracing Papua New Guinea imprint on the central Equatorial Pacific Ocean using neodymium isotopic compositions and Rare Earth Elements concentrations. Earth Planet. Sci. Lett., 186: 497-512.

Lacan, F., Jeandel, C., 2005. Neodymium isotopes as a new tool for quantifying exchange fluxes at the continent-ocean interface. Earth and Planetary Science Letters, 232(3-4): 245-257.

Lacan, F., Tachikawa, K., Jeandel, C., 2012. Neodymium isotopic composition of the oceans: A compilation of seawater data. Chemical Geology, 300-301(0): 177-184.

Lambelet, M., van de Flierdt, T., Crocket, K., Rehkämper, M., Kreissig, K., Coles, B., Rijkenberg, M.J.A., Gerringa, L.J.A., de Baar, H.J.W., Steinfeldt, R., 2016. Neodymium isotopic composition and concentration in the western North Atlantic Ocean: Results from the GEOTRACES GA02 section. Geochimica et Cosmochimica Acta, 177: 1-29.

Lang, D.C., Bailey, I., Wilson, P.A., Chalk, T.B., Foster, G.L., Gutjahr, M., 2016. Incursions of southern-sourced water into the deep North Atlantic during late Pliocene glacial intensification. Nature Geosci, 9(5): 375-379.

Le Houedec, S., Meynadier, L., Allègre, C.J., 2016. Seawater Nd isotope variation in the Western Pacific Ocean since $80 \mathrm{Ma}$ (ODP 807, Ontong Java Plateau). Marine Geology, 380: 138-147.

Lerner, P., Marchal, O., Lam, P.J., Anderson, R.F., Buesseler, K., Charette, M.A., Edwards, R.L., Hayes, C.T., Huang, K.-F., Lu, Y., Robinson, L.F., Solow, A., 2016. Testing models of thorium and particle cycling in the ocean using data from station GT1122 of the U.S. GEOTRACES North Atlantic section. Deep Sea Research Part I: Oceanographic Research Papers, 113: 57-79. 
Lippold, J., Gutjahr, M., Blaser, P., Christner, E., de Carvalho Ferreira, M.L., Mulitza, S., Christl, M., Wombacher, F., Böhm, E., Antz, B., Cartapanis, O., Vogel, H., Jaccard, S.L., 2016. Deep water provenance and dynamics of the (de)glacial Atlantic meridional overturning circulation. Earth and Planetary Science Letters, 445: 6878.

Locarnini, R.A., Mishonov, A.V., Antonov, J.I., Boyer, T.P., Garcia, H.E., Baranova, O.K., Zweng, M.M., Johnson, D.R., 2010. World Ocean Atlas 2009, Volume 1: Temperature. In: Levitus, S. (Ed.), NOAA Atlas NESDIS 68. U.S. Government Printing Office, Washington, D.C., pp. 184.

López Correa, M., Montagna, P., Joseph, N., Rüggeberg, A., Fietzke, J., Flögel, S., Dorschel, B., Goldstein, S.L., Wheeler, A., Freiwald, A., 2012. Preboreal onset of cold-water coral growth beyond the Arctic Circle revealed by coupled radiocarbon and Useries dating and neodymium isotopes. Quaternary Science Reviews, 34(0): 2443.

Maccali, J., Hillaire-Marcel, C., Carignan, J., Reisberg, L.C., 2013. Geochemical signatures of sediments documenting Arctic sea-ice and water mass export through Fram Strait since the Last Glacial Maximum. Quaternary Science Reviews, 64(0): 136151.

Maher, B.A., Prospero, J.M., Mackie, D., Gaiero, D., Hesse, P.P., Balkanski, Y., 2010. Global connections between aeolian dust, climate and ocean biogeochemistry at the present day and at the last glacial maximum. Earth-Science Reviews, 99(1-2): 6197.

Martin, E.E., Blair, S.W., Kamenov, G.D., Scher, H.D., Bourbon, E., Basak, C., Newkirk, D.N., 2010. Extraction of $\mathrm{Nd}$ isotopes from bulk deep sea sediments for paleoceanographic studies on Cenozoic time scales. Chemical Geology, 269(3-4): 414-431.

Martin, E.E., Haley, B.A., 2000. Fossil fish teeth as proxies for seawater $\mathrm{Sr}$ and $\mathrm{Nd}$ isotopes. Geochimica Et Cosmochimica Acta, 64(5): 835-847.

Martin, E.E., MacLeod, K.G., Jiménez Berrocoso, A., Bourbon, E., 2012. Water mass circulation on Demerara Rise during the Late Cretaceous based on Nd isotopes. Earth and Planetary Science Letters, 327-328: 111-120.

Martin, E.E., Scher, H.D., 2004. Preservation of seawater Sr and Nd isotopes in fossil fish teeth: bad news and good news. Earth and Planetary Science Letters, 220(1-2): 25-39.

Meinhardt, A.K., Pahnke, K., Böning, P., Schnetger, B., Brumsack, H.J., 2016. Climate change and response in bottom water circulation and sediment provenance in the Central Arctic Ocean since the Last Glacial. Chemical Geology, 427: 98-108.

Moiroud, M., Pucéat, E., Donnadieu, Y., Bayon, G., Moriya, K., Deconinck, J.-F., Boyet, M., 2013. Evolution of the neodymium isotopic signature of neritic seawater on a northwestern Pacific margin: new constrains on possible end-members for the composition of deep-water masses in the Late Cretaceous ocean. Chemical Geology, 356(0): 160-170.

Molina-Kescher, M., Frank, M., Hathorne, E.C., 2014. Nd and Sr isotope compositions of different phases of surface sediments in the South Pacific: Extraction of seawater signatures, boundary exchange, and detrital/dust provenance. Geochemistry, Geophysics, Geosystems, 15(9): 3502-3520.

Montero-Serrano, J.-C., Frank, N., Tisnerat-Laborde, N., Colin, C., Wu, C.-C., Lin, K., Shen, C.-C., Copard, K., Orejas, C., Gori, A., De Mol, L., Van Rooij, D., Reverdin, G., Douville, E., 2013. Decadal changes in the mid-depth water mass dynamic of the 
Northeastern Atlantic margin (Bay of Biscay). Earth and Planetary Science Letters, 364(0): 134-144.

Montero-Serrano, J.C., Bout-Roumazeilles, V., Carlson, A.E., Tribovillard, N., Bory, A., Meunier, G., Sionneau, T., Flower, B.P., Martinez, P., Billy, I., Riboulleau, A., 2011. Contrasting rainfall patterns over North America during the Holocene and Last Interglacial as recorded by sediments of the northern Gulf of Mexico. Geophysical Research Letters, 38: 6.

Motulsky, H., Christopoulos, A., 2004. Fitting Models to Biological Data using Linear and Nonlinear Regression. Oxford University Press, New York.

Murphy, D.P., Thomas, D.J., 2010. The negligible role of intermediate water circulation in stadial-interstadial oxygenation variations along the southern California margin: Evidence from Nd isotopes. Quaternary Science Reviews, 29(19-20): 2442-2450.

Noble, T.L., Piotrowski, A.M., McCave, I.N., 2013. Neodymium isotopic composition of intermediate and deep waters in the glacial southwest Pacific. Earth and Planetary Science Letters, 384(0): 27-36.

Oka, A., Hasumi, H., Obata, H., Gamo, T., Yamanaka, Y., 2009. Study on vertical profiles of rare earth elements by using an ocean general circulation model. Global Biogeochem. Cycles, 23(4): GB4025.

Osborne, A.H., Haley, B.A., Hathorne, E.C., Flögel, S., Frank, M., 2014. Neodymium isotopes and concentrations in Caribbean seawater: Tracing water mass mixing and continental input in a semi-enclosed ocean basin. Earth and Planetary Science Letters, 406(0): 174-186.

Osborne, A.H., Haley, B.A., Hathorne, E.C., Plancherel, Y., Frank, M., 2015. Rare earth element distribution in Caribbean seawater: Continental inputs versus lateral transport of distinct REE compositions in subsurface water masses. Marine Chemistry, 177, Part 1: 172-183.

Pahnke, K., Goldstein, S.L., Hemming, S.R., 2008. Abrupt changes in Antarctic Intermediate Water circulation over the past 25,000 years. Nature geoscience, 1 : 870-874.

Palmer, M.R., Elderfield, H., 1985. Variations in the $\mathrm{Nd}$ isotopic composition of foraminifera from Atlantic Ocean sediments. Earth and Planetary Science Letters, 73: 299-305.

Pena, L.D., Goldstein, S.L., 2014. Thermohaline circulation crisis and impacts during the mid-Pleistocene transition. Science, 345(6194): 318-322.

Pena, L.D., Goldstein, S.L., Hemming, S.R., Jones, K.M., Calvo, E., Pelejero, C., Cacho, I., 2013. Rapid changes in meridional advection of Southern Ocean intermediate waters to the tropical Pacific during the last 30 kyr. Earth and Planetary Science Letters, 368(0): 20-32.

Piotrowski, A.M., Banakar, V.K., Scrivner, A.E., Elderfield, H., Galy, A., Dennis, A., 2009. Indian Ocean circulation and productivity during the last glacial cycle. Earth and Planetary Science Letters, 285(1-2): 179-189.

Piotrowski, A.M., Galy, A., Nicholl, J.A.L., Roberts, N., Wilson, D.J., Clegg, J.A., Yu, J., 2012. Reconstructing deglacial North and South Atlantic deep water sourcing using foraminiferal Nd isotopes. Earth and Planetary Science Letters, 357-358(0): 289297.

Piotrowski, A.M., Goldstein, S.L., Hemming, S.R., Fairbanks, R.G., 2004. Intensification and variability of ocean thermohaline circulation through the last deglaciation. Earth and Planetary Science Letters, 225(1-2): 205-220. 
Piotrowski, A.M., Goldstein, S.L., Hemming, S.R., Fairbanks, R.G., 2005. Temporal relationships of carbon cycling and ocean circulation at glacial boundaries. Science, 307: 1933-1938.

Piotrowski, A.M., Goldstein, S.L., R, H.S., Fairbanks, R.G., Zylberberg, D.R., 2008. Oscillating glacial northern and southern deep water formation from combined neodymium and carbon isotopes. Earth and Planetary Science Letters, 272(1-2): 394-405.

Puceat, E., Lecuyer, C., Reisberg, L., 2005. Neodymium isotope evolution of NW Tethyan upper ocean waters throughout the Cretaceous. Earth and Planetary Science Letters, 236(3-4): 705-720.

Rempfer, J., Stocker, T.F., Joos, F., Dutay, J.-C., Siddall, M., 2011. Modelling Nd-isotopes with a coarse resolution ocean circulation model: Sensitivities to model parameters and source/sink distributions. Geochimica Et Cosmochimica Acta, 75(20): 5927-5950.

Rickli, J., Frank, M., Baker, A.R., Aciego, S., de Souza, G., Georg, R.B., Halliday, A.N., 2010. Hafnium and neodymium isotopes in surface waters of the eastern Atlantic Ocean: Implications for sources and inputs of trace metals to the ocean. Geochimica Et Cosmochimica Acta, 74(2): 540-557.

Rickli, J., Frank, M., Halliday, A.N., 2009. The hafnium-neodymium isotopic composition of Atlantic seawater. Earth and Planetary Science Letters, 280(1-4): 118-127.

Roberts, N.L., Piotrowski, A.M., 2015. Radiogenic Nd isotope labeling of the northern NE Atlantic during MIS 2. Earth and Planetary Science Letters, 423(0): 125-133.

Roberts, N.L., Piotrowski, A.M., McManus, J.F., Keigwin, L.D., 2010. Synchronous Deglacial Overturning and Water Mass Source Changes. Science, 327(5961): 75-78.

Robinson, L.F., van de Flierdt, T., 2009. Southern Ocean evidence for reduced export of North Atlantic Deep Water during Heinrich event 1. Geology, 37(3): 195-198.

Robinson, S.A., Murphy, D.P., Vance, D., Thomas, D.J., 2010. Formation of "Southern Component Water" in the Late Cretaceous: Evidence from Nd-isotopes. Geology, 38(10): 871-874.

Rousseau, T.C.C., Sonke, J.E., Chmeleff, J., van Beek, P., Souhaut, M., Boaventura, G., Seyler, P., Jeandel, C., 2015. Rapid neodymium release to marine waters from lithogenic sediments in the Amazon estuary. Nat Commun, 6.

Roy-Barman, M., Lemaitre, C., Ayrault, S., Jeandel, C., Souhaut, M., Miquel, J.C., 2009. The influence of particle composition on Thorium scavenging in the Mediterranean Sea. Earth and Planetary Science Letters, 286(3-4): 526-534.

Rutberg, R.L., Hemming, S.R., Goldstein, S.L., 2000. Reduced North Atlantic Deep Water flux to the glacial Southern Ocean inferred from neodymium isotopic ratios. Nature, 405: 935-938.

Schlitzer, R., 2015. Ocean data view. In: http://odv.awi.de. (Editor).

Schmittner, A., Gruber, N., Mix, A.C., Key, R.M., Tagliabue, A., Westberry, T.K., 2013. Biology and air-sea gas exchange controls on the distribution of carbon isotope ratios $\left(\delta^{13} \mathrm{C}\right)$ in the ocean. Biogeosciences, $10(9)$ : 5793-5816.

Scrivner, A.E., Vance, D., Rohling, E.J., 2004. New neodymium isotope data quantify Nile involvement in Mediterranean anoxic episodes. Geology, 32(7): 565-568.

Seiter, K., Hensen, C., Schröter, J., Zabel, M., 2004. Organic carbon content in surface sediments-defining regional provinces. Deep Sea Research Part I: Oceanographic Research Papers, 51(12): 2001-2026. 
Sholkovitz, E.R., 1992. Chemical evolution of rare earth elements: fractionation between colloidal and solution phases of filtered river water. Earth Planet. Sci. Lett, 114: 77-84.

Siddall, M., Khatiwala, S., van de Flierdt, T., Jones, K., Goldstein, S.L., Hemming, S., Anderson, R.F., 2008. Towards explaining the Nd paradox using reversible scavenging in an ocean general circulation model. Earth and Planetary Science Letters, 274(3-4): 448-461.

Singh, S.P., Singh, S.K., Goswami, V., Bhushan, R., Rai, V.K., 2012. Spatial distribution of dissolved neodymium and $\varepsilon_{\mathrm{Nd}}$ in the Bay of Bengal: Role of particulate matter and mixing of water masses. Geochimica Et Cosmochimica Acta, 94(0): 38-56.

Skinner, L.C., Scrivner, A.E., Vance, D., Barker, S., Fallon, S., Waelbroeck, C., 2013. North Atlantic versus Southern Ocean contributions to a deglacial surge in deep ocean ventilation. Geology, 41(6): 667-670.

Stichel, T., Frank, M., Rickli, J., Haley, B.A., 2012. The hafnium and neodymium isotope composition of seawater in the Atlantic sector of the Southern Ocean. Earth and Planetary Science Letters, 317-318(0): 282-294.

Stichel, T., Hartman, A.E., Duggan, B., Goldstein, S.L., Scher, H., Pahnke, K., 2015. Separating biogeochemical cycling of neodymium from water mass mixing in the Eastern North Atlantic. Earth and Planetary Science Letters, 412(0): 245-260.

Stoll, H.M., Vance, D., Arevalos, A., 2007. Records of the $\mathrm{Nd}$ isotope composition of seawater from the Bay of Bengal: Implications for the impact of Northern Hemisphere cooling on ITCZ movement. Earth and Planetary Science Letters, 255(1-2): 213-228.

Stordal, M.C., Wasserburg, G.J., 1986. Neodymium isotopic study of Baffin Bay water: sources of REE from very old terranes. Earth Planet. Sci. Lett., 77: 259-272.

Stumpf, R., Frank, M., Schonfeld, J., Haley, B.A., 2010. Late Quaternary variability of Mediterranean Outflow Water from radiogenic $\mathrm{Nd}$ and $\mathrm{Pb}$ isotopes. Quaternary Science Reviews, 29(19-20): 2462-2472.

Tachikawa, K., Athias, V., Jeandel, C., 2003. Neodymium budget in the modern ocean and paleo-oceanographic implications. J. Geophys. Res., 108(C8): 3254.

Tachikawa, K., Jeandel, C., Roy-Barman, M., 1999a. A new approach to the Nd residence time in the ocean: the role of atmospheric inputs. Earth and Planetary Science Letters, 170(4): 433-446.

Tachikawa, K., Jeandel, C., Vangriesheim, A., Dupre, B., 1999b. Distribution of rare earth elements and neodymium isotopes in suspended particles of the tropical Atlantic Ocean (EUMELI site). Deep Sea Research Part I: Oceanographic Research Papers, 46(5): 733-755.

Tachikawa, K., Piotrowski, A.M., Bayon, G., 2014. Neodymium associated with foraminiferal carbonate as a recorder of seawater isotopic signatures. Quaternary Science Reviews, 88(0): 1-13.

Tachikawa, K., Roy-Barman, M., Michard, A., Thouron, D., Yeghicheyan, D., Jeandel, C., 2004. Neodymium isotopes in the Mediterranean Sea: comparison between seawater and sediment signals. Geochimica Et Cosmochimica Acta, 68(14): 30953106.

Thomas, D.J., 2004. Evidence for deep-water production in the North Pacific Ocean during the early Cenozoic warm interval. Nature, 430(6995): 65-68.

Thomas, D.J., Korty, R., Huber, M., Schubert, J.A., Haines, B., 2014. Nd Isotopic Structure of the Pacific Ocean 70-30 Ma and Numerical Evidence for Vigorous Ocean 
Circulation and Ocean Heat Transport in a Greenhouse World. Paleoceanography: 2013PA002535.

van de Flierdt, T., Frank, M., 2010. Neodymium isotopes in paleoceanography. Quaternary Science Reviews, 29(19-20): 2439-2441.

van de Flierdt, T., Griffiths, A.M., Lambelet, M., Little, S.H., Stichel, T., Wilson, D.J., 2016. Neodymium in the oceans: a global database, a regional comparison and implications for palaeoceanographic research. Philosophical Transactions of the Royal Society A: Mathematical, Sciences, 374(2081).

Physical and Engineering

van de Flierdt, T., Pahnke, K., participants, G.i., 2012. GEOTRACES intercalibration of neodymium isotopes and rare earth element concentrations in seawater and suspended particles. Part 1: reproducibility of results for the international intercomparison. Limnol. Oceanogr.: Methods, 10: 234-251.

van de Flierdt, T., Robinson, L.F., Adkins, J.F., 2010. Deep-sea coral aragonite as a recorder for the neodymium isotopic composition of seawater. Geochimica Et Cosmochimica Acta, 74(21): 6014-6032.

Vance, D., Burton, K., 1999. Neodymium isotopes in planktonic foraminifera: a record of the response of continental weathering and ocean circulation rates to climate change. Earth Planet. Sci. Lett., 173: 365-379.

Vance, D., Scrivner, A.E., Benecy, P., Staubwasser, M., Henderson, G.M., 2004. The use of foraminifera as a record of the past neodymium isotope composition of seawater. Paleoceanography, 19(PA2009): doi:10.1029/2003PA000957.

von Blanckenburg, F., 1999. Tracing Past Ocean Circulation? Science, 286(5446): 18621863.

Wei, R., Abouchami, W., Zahn, R., Masque, P., 2016. Deep circulation changes in the South Atlantic since the Last Glacial Maximum from $\mathrm{Nd}$ isotope and multi-proxy records. Earth and Planetary Science Letters, 434: 18-29.

Werner, K., Frank, M., Teschner, C., Müller, J., Spielhagen, R.F., 2014. Neoglacial change in deep water exchange and increase of sea-ice transport through eastern Fram Strait: evidence from radiogenic isotopes. Quaternary Science Reviews, 92(0): 190-207.

Wilson, D.J., Crocket, K.C., van de Flierdt, T., Robinson, L.F., Adkins, J.F., 2014. Dynamic intermediate ocean circulation in the North Atlantic during Heinrich Stadial 1: A radiocarbon and neodymium isotope perspective. Paleoceanography, 29(11): 2014 PA002674.

Wilson, D.J., Piotrowski, A.M., Galy, A., Clegg, J.A., 2013. Reactivity of neodymium carriers in deep sea sediments: Implications for boundary exchange and paleoceanography. Geochimica Et Cosmochimica Acta, 109(0): 197-221.

Wilson, D.J., Piotrowski, A.M., Galy, A., McCave, I.N., 2012. A boundary exchange influence on deglacial neodymium isotope records from the deep western Indian Ocean. Earth and Planetary Science Letters, 341-344(0): 35-47.

Wu, Q., Colin, C., Liu, Z., Douville, E., Dubois-Dauphin, Q., Frank, N., 2015a. New insights into hydrological exchange between the South China Sea and the Western Pacific Ocean based on the Nd isotopic composition of seawater. Deep Sea Research Part II: Topical Studies in Oceanography, 122: 25-40.

Wu, Q., Colin, C., Liu, Z., Thil, F., Dubois-Dauphin, Q., Frank, N., Tachikawa, K., Bordier, L., Douville, E., 2015b. Neodymium isotopic composition in foraminifera and authigenic phases of the South China Sea sediments: Implications for the 
hydrology of the North Pacific Ocean over the past 25 kyr. Geochemistry, Geophysics, Geosystems, 16(11): 3883-3904.

Xie, R.C., Marcantonio, F., Schmidt, M.W., 2012. Deglacial variability of Antarctic Intermediate Water penetration into the North Atlantic from authigenic neodymium isotope ratios. Paleoceanography, 27(3): PA3221.

Yasuda, I., Okuda, K., Shimizu, Y., 1996. Distribution and Modification of North Pacific Intermediate Water in the Kuroshio-Oyashio Interfrontal Zone. Journal of Physical Oceanography, 26(4): 448-465.

Yu, J., Elderfield, H., Piotrowski, A.M., 2008. Seawater carbonate ion- $\delta^{13} \mathrm{C}$ systematics and application to glacial-interglacial North Atlantic ocean circulation. Earth and Planetary Science Letters, 271(1-4): 209-220.

Zheng, X.-Y., Plancherel, Y., Saito, M.A., Scott, P.M., Henderson, G.M., 2016. Rare earth elements (REEs) in the tropical South Atlantic and quantitative deconvolution of their non-conservative behavior. Geochimica et Cosmochimica Acta, 177: 217237. 
Table 1. Mean seawater $\varepsilon_{\mathrm{Nd}}$ values and Nd concentrations for major water masses estimated from NEOSYMPA database

\begin{tabular}{|c|c|c|c|c|c|c|c|c|c|c|c|}
\hline $\begin{array}{l}\text { Water } \\
\text { mass }\end{array}$ & Basin & $\varepsilon_{\mathrm{Nd}}$ & $1 \sigma$ & $\mathrm{n}$ & $\begin{array}{c}\mathrm{Nd} \\
(\mathrm{pmol} / \mathrm{kg})\end{array}$ & $1 \sigma$ & $\mathrm{n}$ & Salinity & $1 \sigma$ & $\begin{array}{l}\text { Temp } \\
\left({ }^{\circ} \mathrm{C}\right)\end{array}$ & $1 \sigma$ \\
\hline AABW & S. Atlantic & -8.6 & 0.6 & 39 & 25.5 & 3.1 & 37 & 34.680 & 0.020 & -0.110 & 0.44 \\
\hline NADW & N. Atlantic & -12.3 & 0.9 & 173 & 20.3 & 3.2 & 135 & 34.933 & 0.035 & 2.567 & 0.632 \\
\hline AAIW & S. Atlantic & -8.6 & 1.4 & 28 & 12.1 & 1.9 & 28 & 34.430 & 0.159 & 3.270 & 1.02 \\
\hline CDW & S. Indian & -7.9 & 1.3 & 10 & 27.6 & 1.6 & 9 & 34.723 & 0.007 & 1.058 & 0.28 \\
\hline AAIW & S. Indian & -7.6 & 0.9 & 4 & 12.9 & 2.1 & 4 & 34.703 & 0.096 & 6.205 & 1.48 \\
\hline CDW & S. Pacific & -7.8 & 1.2 & 92 & 24.0 & 4.8 & 87 & 34.702 & 0.019 & 0.624 & 0.551 \\
\hline NPDW & N. Pacific & -4.3 & 1.2 & 84 & 39.2 & 9.6 & 45 & 34.672 & 0.019 & 1.006 & 0.371 \\
\hline AAIW & S. Pacific & -7.7 & 1.1 & 21 & 9.6 & 2.1 & 19 & 34.306 & 0.081 & 4.708 & 1.35 \\
\hline EqPIW & Pacific & -3.0 & 1.4 & 31 & 11.6 & 5.9 & 30 & 34.537 & 0.029 & 5.346 & 0.863 \\
\hline NPIW & N. Pacific & -3.4 & 1.3 & 12 & 14.3 & 2.2 & 6 & 34.122 & 0.075 & 6.671 & 0.754 \\
\hline PEW & Pacific & -2.1 & 0.9 & 72 & 6.5 & 2.5 & 64 & 35.017 & 0.307 & 14.33 & 4.192 \\
\hline
\end{tabular}

AABW: Antarctic Bottom Water

NADW: North Atlantic Deep Water

AAIW: Antarctic Intermediate Water

CDW: Circumpolar Deep Water

NPDW: North Pacific Deep Water

EqPIW: Equatorial Pacific Intermediate Water

NPIW: North Pacific Intermediate Water

PEW: Pacific Equatorial Water 

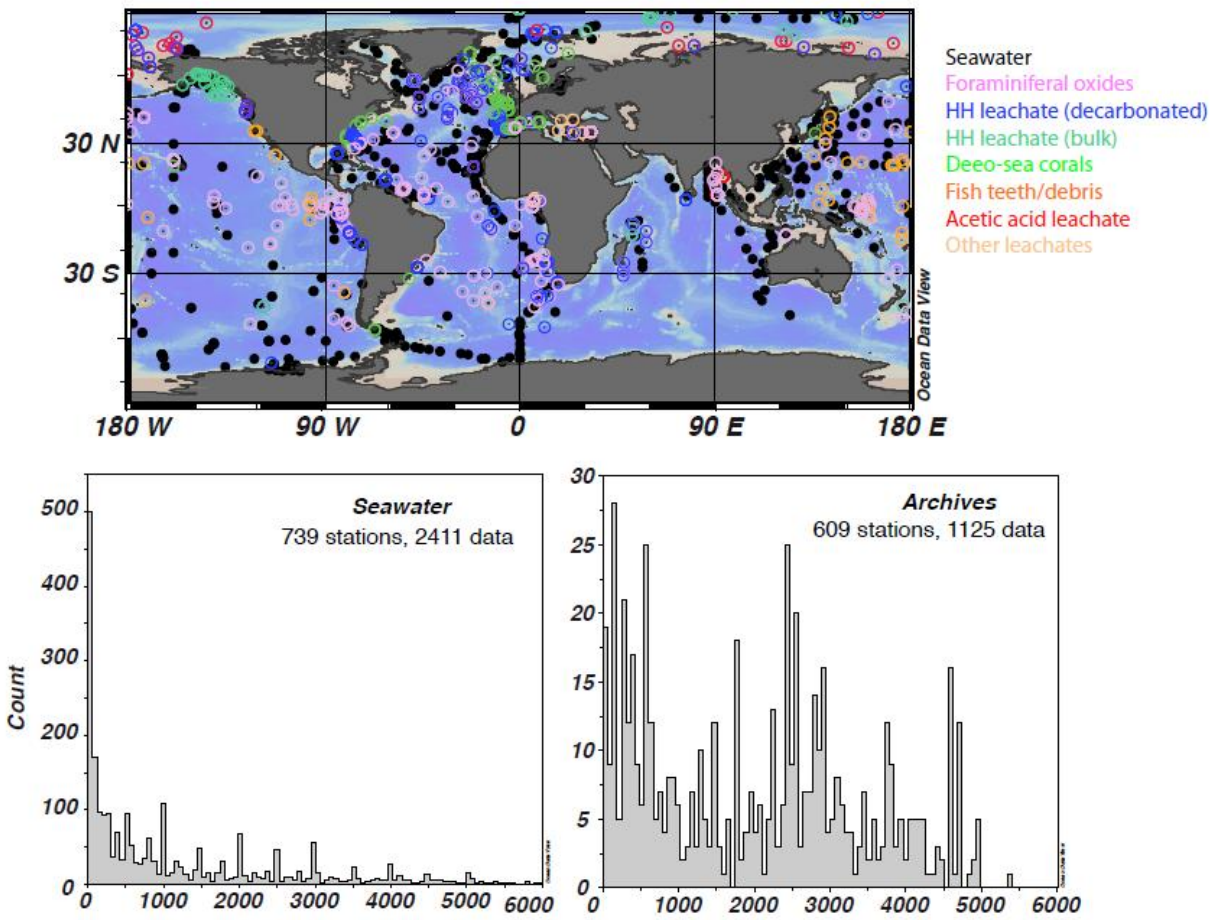

Fig. 1

Water depth [m] 

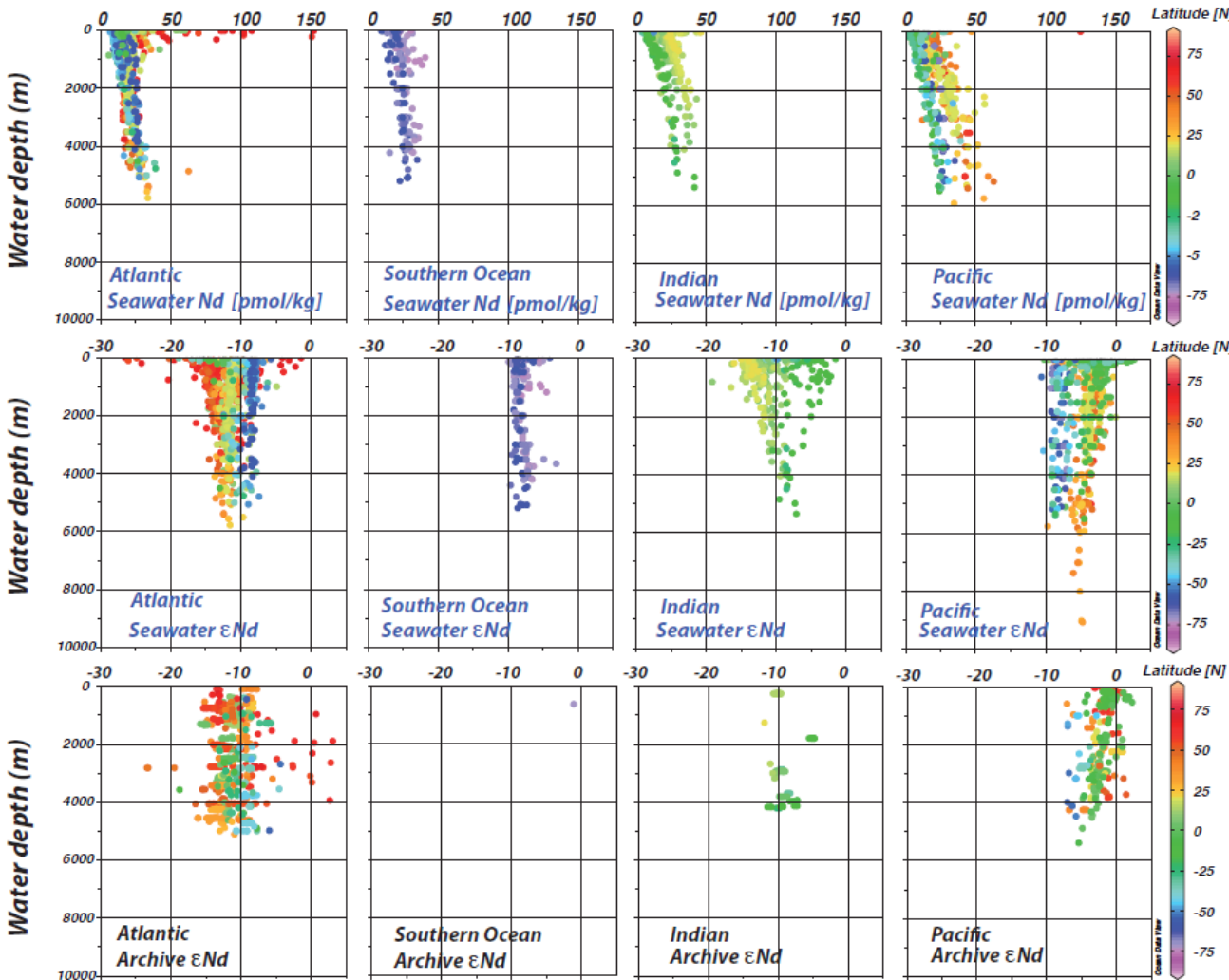

Fig. 2 

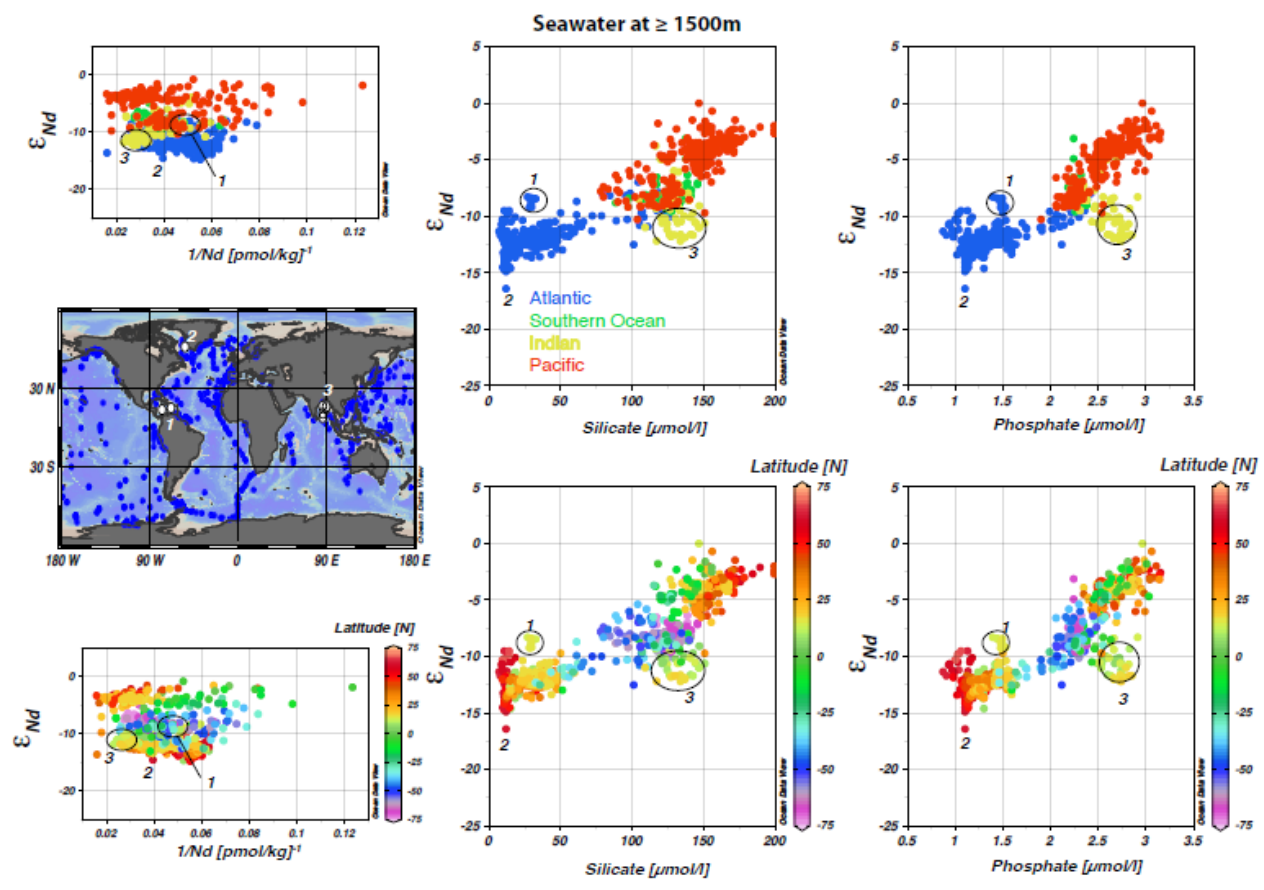

Fig. 3 

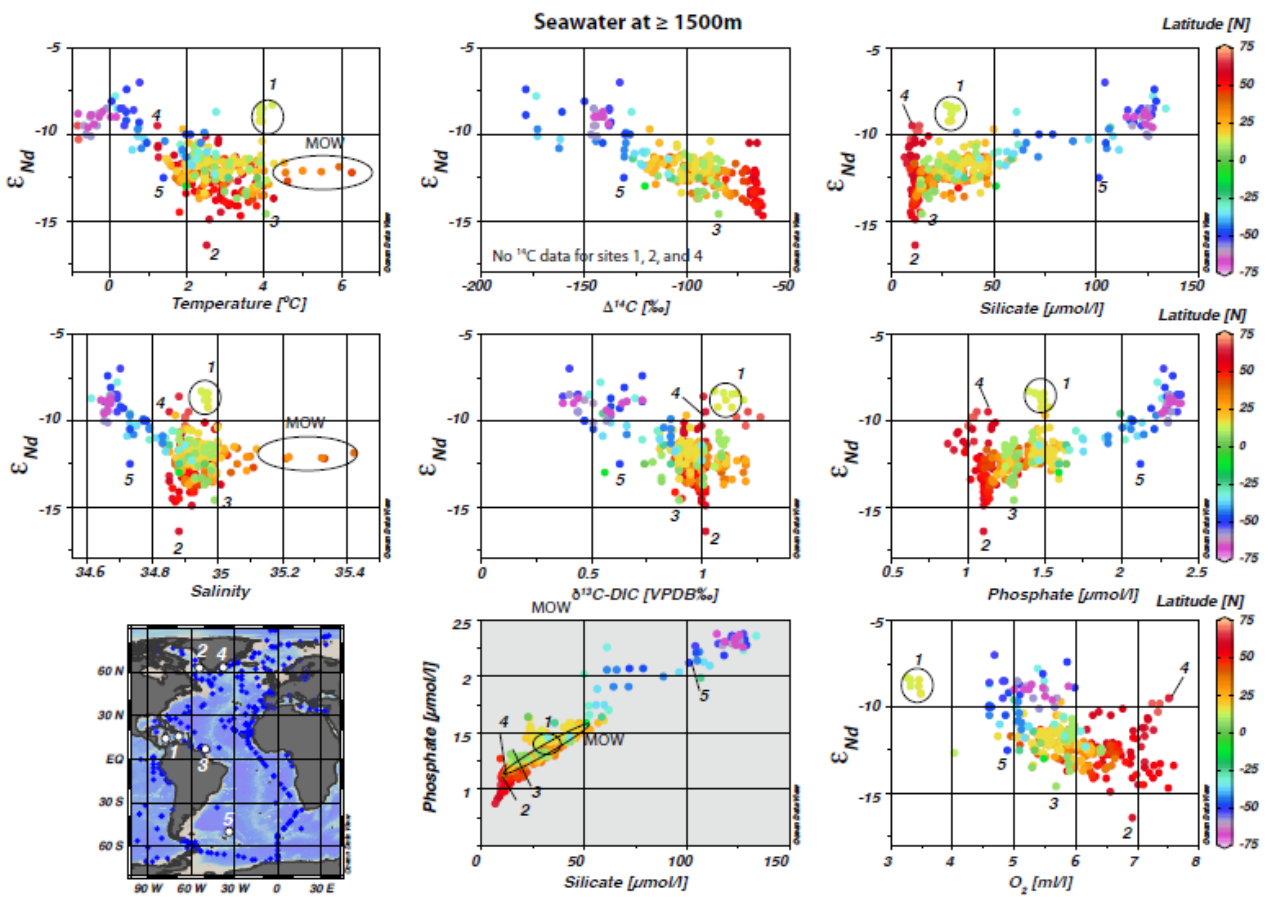

Fig. $4 a$ 

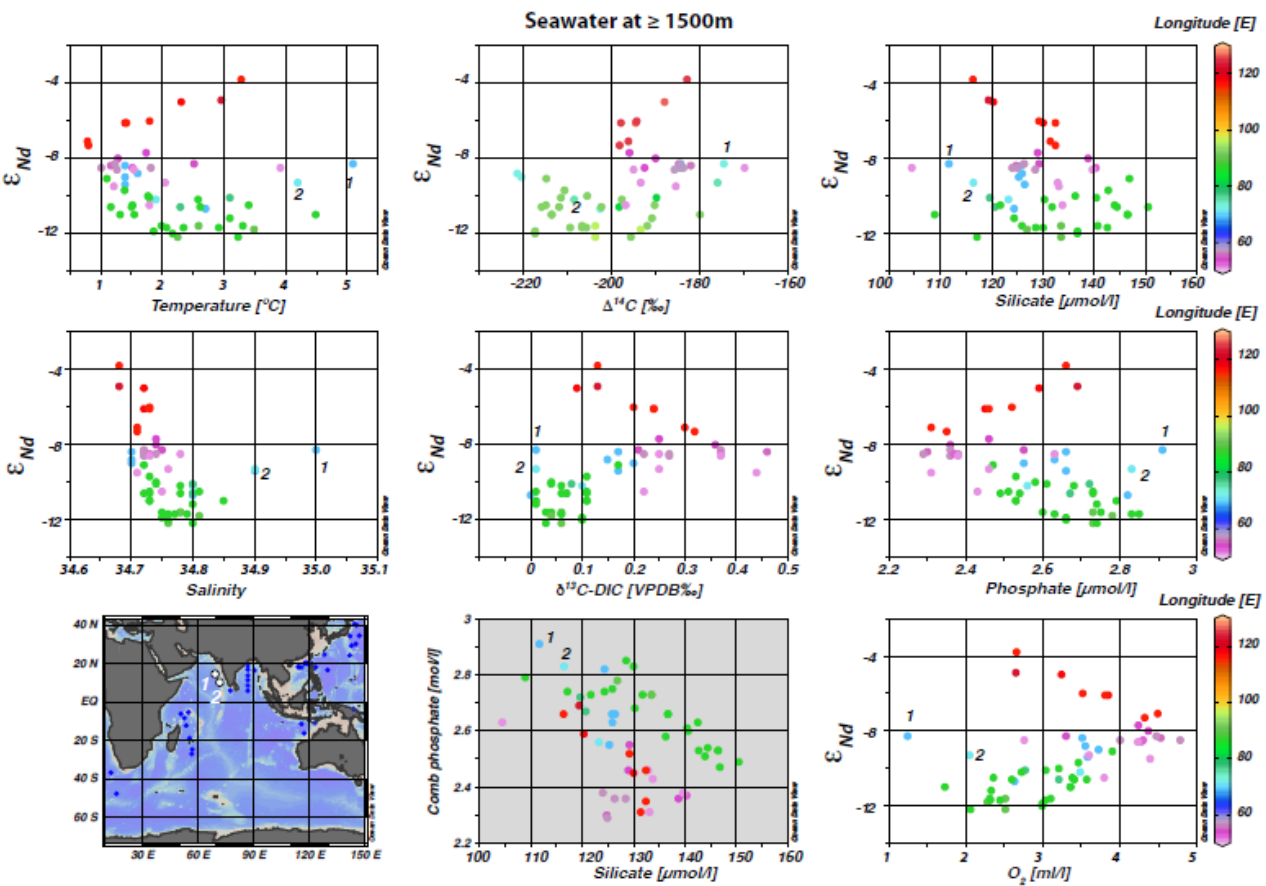

Fig. 4b 

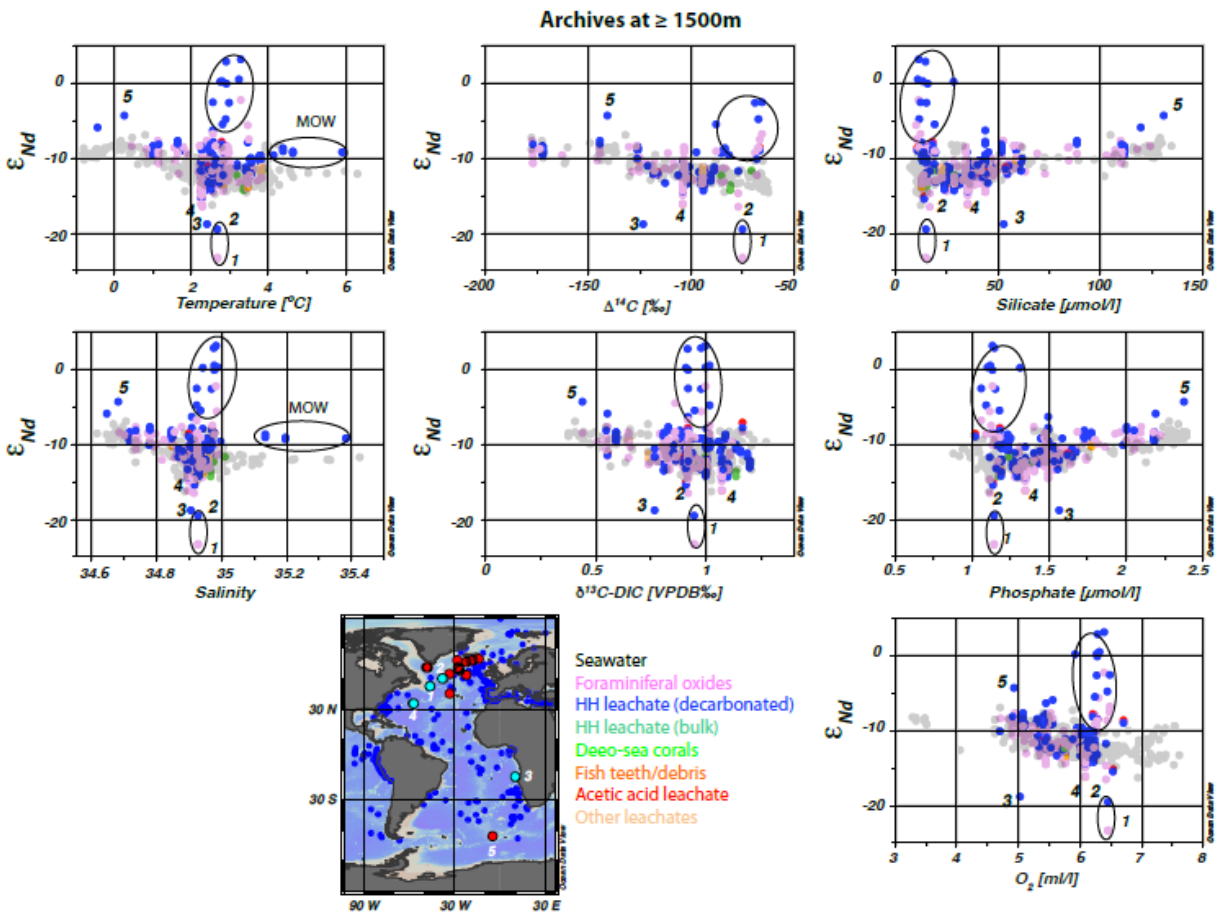

Fig. 5a 

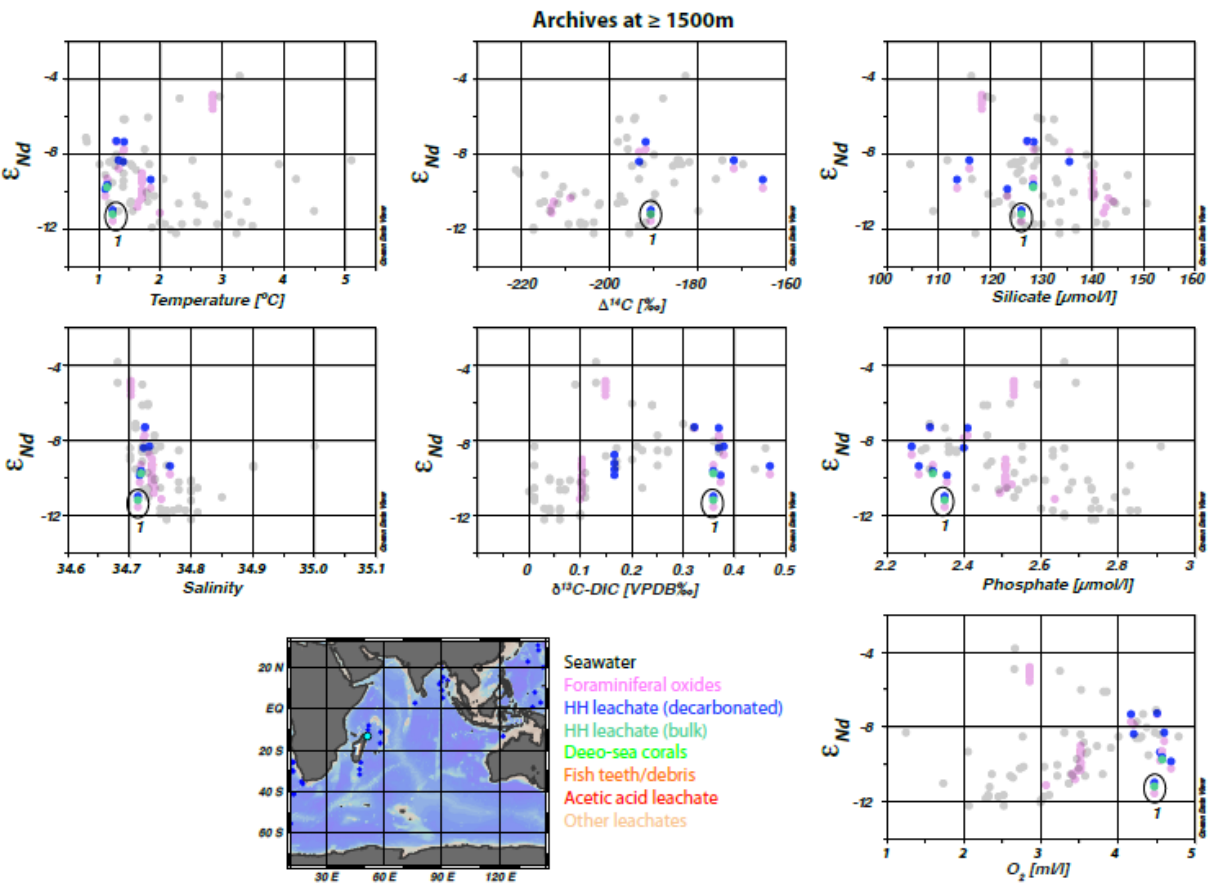

Fig. 5b 

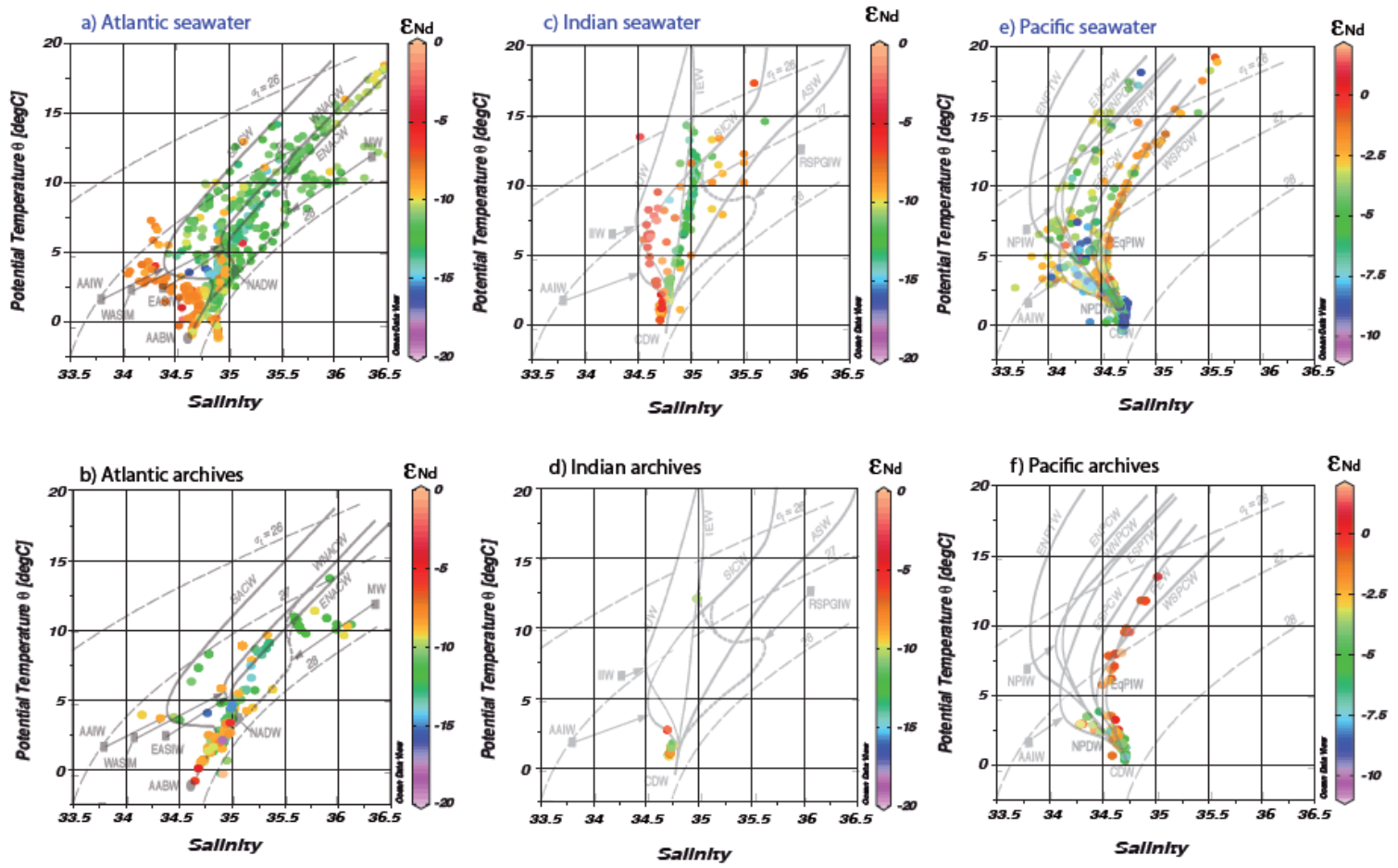

Fig. 6 
Figure
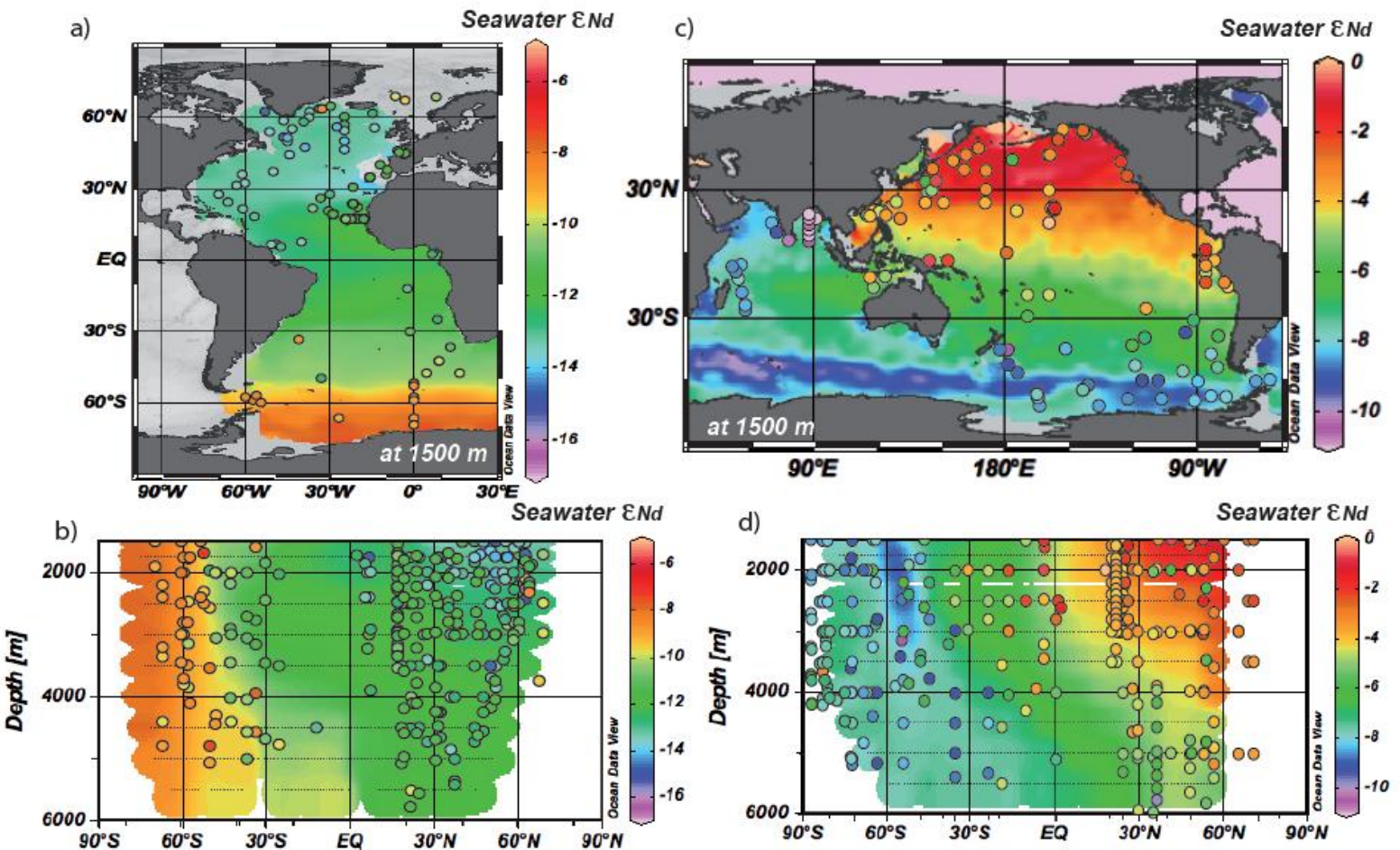

Fig. 7 

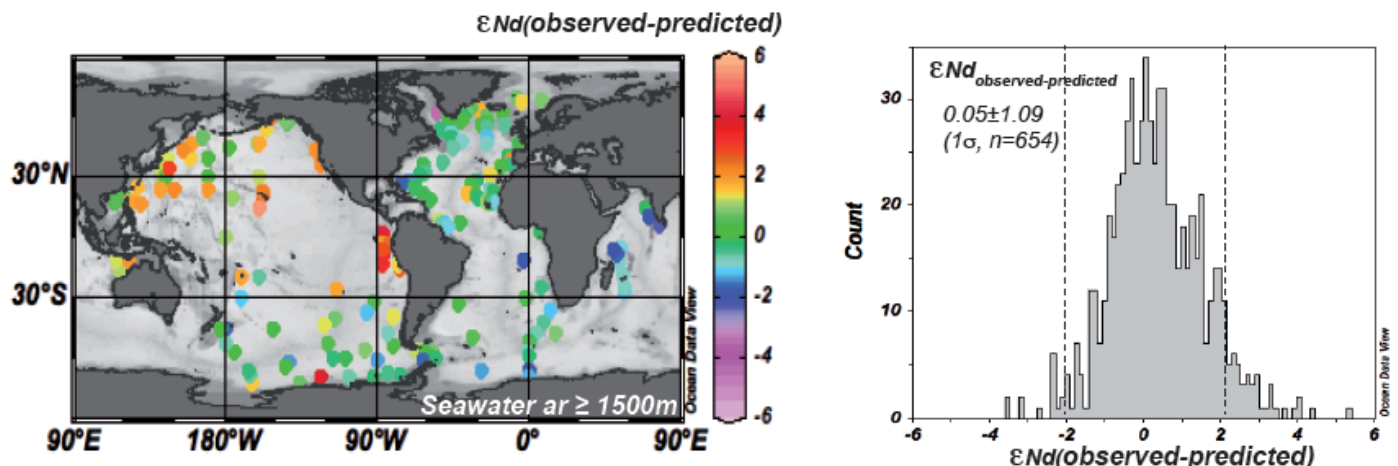

Fig. 8
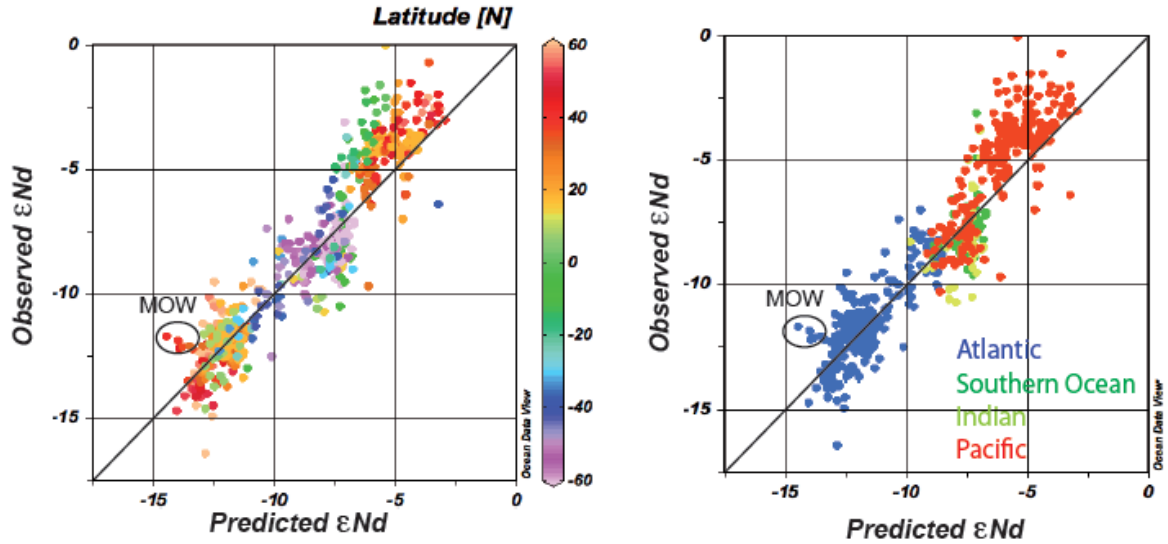
a) Seawater at $\geq 1500 \mathrm{~m}$

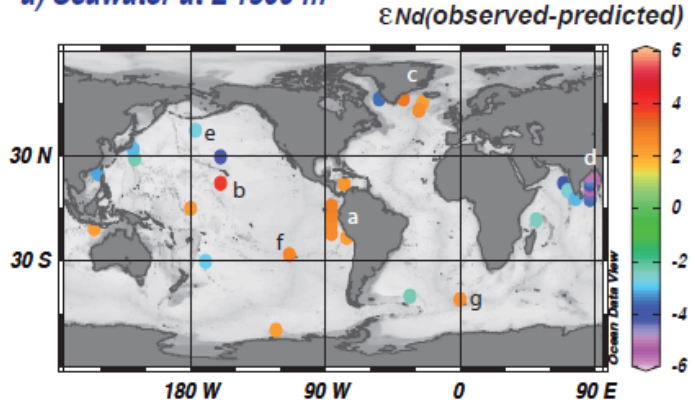

b) Seawater at $\geq 1500 \mathrm{~m}$

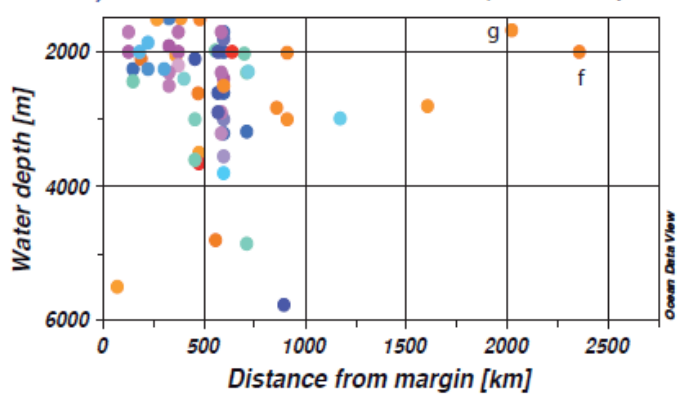

Fig. 9

\section{c) Archives at $\geq 1500 \mathrm{~m}$}

$\varepsilon N d($ observed-predicted)

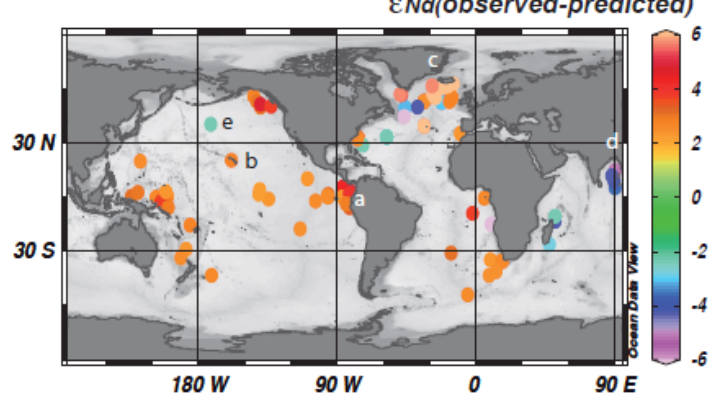

d) Archives at $\geq 1500 \mathrm{~m} \quad \varepsilon N d($ observed-predicted)

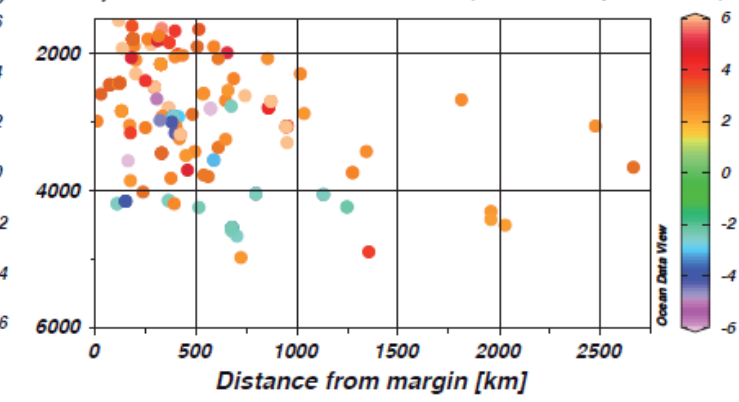


Figure
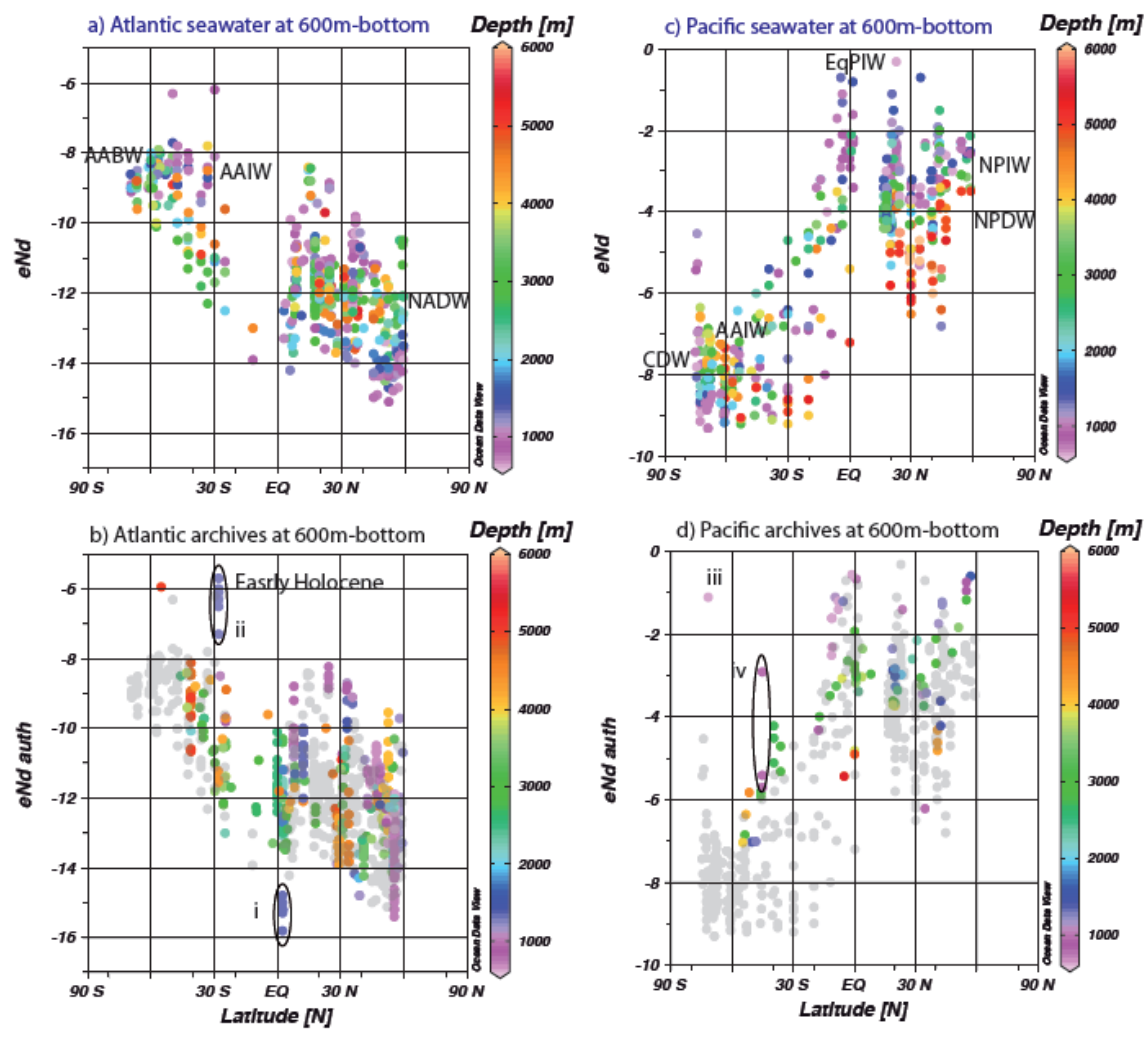

Fig. 10 